Research Paper

\title{
The Spleen Tyrosine Kinase Inhibitor, Entospletinib (GS-9973) Restores Chemosensitivity in Lung Cancer Cells by Modulating ABCG2-mediated Multidrug Resistance
}

\begin{abstract}
Silpa Narayanan ${ }^{1}$, Zhuo-Xun Wu${ }^{1}$, Jing-Quan Wang ${ }^{1}$, Hansu Ma², Nikita Acharekar ${ }^{1}$, Jagadish Koya ${ }^{1}$, Sabesan Yoganathan ${ }^{1}$, Shuo Fang ${ }^{\circledR}$, Zhe-Sheng Chen ${ }^{1}$ and Yihang $\operatorname{Pan}^{2}{ }^{\circledR}$

1. Department of Pharmaceutical Sciences, College of Pharmacy and Health Sciences, St. John's University, Queens, NY, 11439, USA.

2. Precision Medicine Center, The Seventh Affiliated Hospital, Sun Yat-Sen University, Shenzhen 518107, PR China.

3. Department of Oncology, The Seventh Affiliated Hospital, Sun Yat-Sen University, Shenzhen, 518107, PR China.

$\square$ Corresponding authors: Yihang Pan, Precision Medicine Center, The Seventh Affiliated Hospital, Sun Yat-sen University, Shenzhen 518107, PR China. E-mail: panyih@mail.sysu.edu.cn; Phone: 86-0755-81206008; Fax: 86-0755-81206211; Zhe-Sheng Chen, Department of Pharmaceutical Sciences, College of Pharmacy and Health Sciences, St. John's University, Queens, NY, 11439, USA. E-mail: chenz@stjohns.edu; Phone: 1-718-990-1432; Fax: 1-718-990-1877; Shuo Fang, Department of Oncology, The Seventh Affiliated Hospital, Sun Yat-Sen University, Shenzhen, China. E-mail: fangsh9@mail.sysu.edu.cn; Phone: 86-0755-81206796; Fax: 86-0755-81206796.
\end{abstract}

(1) The author(s). This is an open access article distributed under the terms of the Creative Commons Attribution License (https://creativecommons.org/licenses/by/4.0/). See http://ivyspring.com/terms for full terms and conditions.

Received: 2021.04.03; Accepted: 2021.06.08; Published: 2021.06.22

\begin{abstract}
Tyrosine kinase inhibitors (TKIs) are important in managing lymphoid malignancies by targeting B-cell receptor signaling pathways. Entospletinib (GS-9973) is an oral, selective inhibitor of spleen tyrosine kinase (Syk), currently in the phase II clinical trials for the treatment of chronic lymphocytic leukemia. Syk is abundantly present in the cells of hematopoietic lineage that mediates cell proliferation, differentiation, and adhesion. In this current study, we evaluated the efficacy of GS-9973 to overcome multidrug resistance (MDR) due to the overexpression of the ABCG2 transporter in the non-small cell lung cancer (NSCLC) cell line, $\mathrm{NCl}-\mathrm{H} 460$ / $\mathrm{MX20}$. In vitro, $3 \mu \mathrm{M}$ of GS-9973 reversed the drug resistance of $\mathrm{NCl}-\mathrm{H} 460 / \mathrm{MX} 20$ cell line to mitoxantrone or doxorubicin. GS-9973, at $3 \mu \mathrm{M}$ reverses ABCG2-mediated MDR by blocking ABCG2 efflux activity and downregulating $A B C G 2$ expression at the protein level but did not alter the $A B C G 2$ mRNA expression and subcellular localization of the ABCG2 protein compared to drug-resistant cells incubated with the vehicle. GS-9973 produced a moderate concentration-dependent increase in the ATPase activity of ABCG2 $\left(E_{50}=\right.$ $0.42 \mu \mathrm{M})$ and molecular docking data indicated that GS-9973 had a high affinity $(-10.226 \mathrm{kcal} / \mathrm{mol})$ for the substrate-binding site of ABCG2. Finally, HPLC analysis proved that the intracellular concentration of GS-9973 is not significantly different in both parental and resistant cell lines. In conclusion, our study suggests that in vitro, GS-9973 in combination with certain anticancer drugs, represent a strategy to overcome ABCG2-mediated MDR cancers.
\end{abstract}

Key words: Entospletinib; Syk; MDR; reversal effect; ATP binding cassette transporter; ABCG2

\section{Introduction}

Lung cancer is the leading source of cancer associated casualties globally, with an estimated 2.21 million cases in the year 2020 and around 1.79 million deaths in 2020, and non-small cell lung cancer (NSCLC) accounts for up to $85 \%$ of the lung cancer cases all around the world [1]. The 5-year survival rate of NSCLC patients from the time of diagnosis was found to be around $15 \%$ because more than $50 \%$ of NSCLC cases are diagnosed at metastatic conditions (stage IV) [2-4]. Regardless of achieving substantial advancements in the treatment of metastatic or locally advanced NSCLC, improving the quality of life in NSCLC patients has been a major challenge [4]. Treatment modalities involving surgery, radiation therapy, and chemotherapy are considered essential to treat NSCLC patients but tumor heterogenicity and multidrug resistance (MDR) remain to be a primary obstacle by limiting chemotherapeutic efficacy 
leading to increased cases of relapse and mortality in NSCLC patients [5-10]. MDR or chemoresistance characterizes a phenomenon where cells exhibit resistance to drugs that are pharmacologically and structurally distinct [11-15]. MDR is orchestrated via different mechanisms [16] among which, adenosine triphosphate binding cassette $(\mathrm{ABC})$ transporters play a substantial role by extruding antineoplastic drugs and cytotoxic agents [14,17-19]. ABC transporter superfamily embodies a ubiquitous range of comprehensive membrane proteins which are classified into seven subfamilies from ABCA to ABCG and are responsible for critical physiological and pharmacological contributions [20-22]. ABCG2 was initially identified in MCF-7 breast cancer cells giving it the nomenclature, breast cancer resistance protein (BCRP) $[23,24]$. ABCG2 has been widely reported to be a principal cause of MDR in various cancers via extruding various antineoplastic drugs such as tyrosine kinase inhibitors (TKIs), topoisomerase inhibitors, anthracyclines, etc. [25-29].

Platinum-based chemotherapy with or without bevacizumab is considered to be the first line of treatment in advanced NSCLC patients lacking targetable tumor-specific mutations [30]. Considering the oncogene mutations and other factors in NSCLC patients, various targeted therapies have been developed such as EGFR specific TKIs targeting EGFR specific mutations, anaplastic lymphoma kinase (ALK) inhibitor targeting ALK-positive patients, and immune checkpoint blockers which substantially improved the quality of life in NSCLC patients over the past 20 years [31-33]. Expression of ABCG2 is associated with a decrease in response to therapy and overall survival in NSCLC patients $[3,8]$. Several studies have established that cancer stem-like cell (CSC) population in cancer expressing ABCG2 limits the efficacy of chemotherapy and is responsible for the re-emergence of tumors during the period of relapse in various cancer patients [34-36]. Studies conducted by Hang et al and Li et al have determined that CSC expressing CD133 and ABCG2 have decreased overall survival, chemotherapeutic response rates, and increased the rate of relapses in NSCLC patients [37,38]. In vitro studies have also demonstrated that several TKIs like imatinib, gefitinib, and nilotinib are substrates of ABCG2 $[39,40]$ or inhibitors of ABCG2 in some studies [41-43]. Due to its potential role in regulating MDR and its association with NSCLC as a prognostic marker, there is a serious need to identify potential drugs that can resensitize ABCG2-mediated drug resistance.

Previous in vitro studies from our lab have shown some of the selective TKIs can sensitize ABCG2-mediated cancer resistance in various cancer scenarios [44-46]. Spleen tyrosine kinase (Syk) is a cytoplasmic tyrosine kinase expressed ubiquitously in hematopoietic cells and in other cell types [47]. Activation of Syk mediates the activation of B cells and $\mathrm{T}$ cells by eliciting the interaction between the $\mathrm{T}$ cell and B cell receptors [48]. Syk signaling is associated with different biological responses comprising cellular proliferation, differentiation, function, development, and adhesion [49]. Entospletinib (GS-9973) is a novel selective Syk inhibitor that is being evaluated for its efficacy in treating hematopoietic malignancies like chronic lymphocytic leukemia (CLL), mantle cell lymphomas, acute myeloid leukemia (AML), etc. [49-51]. In current study, we tried to investigate the efficacy of GS-9973 in antagonizing the ABCG2-mediated chemoresistance in NSCLC cell lines.

\section{Materials and methods}

\section{Chemicals}

GS-9973 (Entospletinib) (Figure 4A) was kindly supplied by Chemietek (Indianapolis, IN). Mitoxantrone was bought from Enzo Sciences (Farmingdale, NY) and doxorubicin was obtained from Medkoo Biosciences (Morrisville, NC). Cisplatin, verapamil, vincristine, 3-(4,5-dimethylthiazol-yl)-2,5diphenyltetrazolium bromide (MTT), and dimethyl sulfoxide (DMSO) were obtained from Sigma Chemical (St. Louis, MO). The cell culture medium, Dulbecco's modified Eagle's medium (DMEM), trypsin and penicillin/streptomycin (P/S) were purchased from Corning Life sciences (Manassas, VA). Ko143 was bought from Enzo Life Sciences (Farmingdale, NY) and $\left[{ }^{3} \mathrm{H}\right]$-mitoxantrone $(4$ $\mathrm{Ci} / \mathrm{mmol}$ ) was acquired from Moravek Biochemicals, Inc (Brea, CA). ABCG2 (D752K) and GAPDH (D16H1) selective monoclonal antibodies and secondary anti-rabbit antibody linked with HRP (7074S) were procured from Cell Signaling Technologies (Danvers, MA). Alexa fluor conjugated secondary antibody was purchased from Molecular Probes (Eugene, OR). Trizol reagent was obtained from Invitrogen Life Technologies (Carlsbad, CA). The ABCG2 and GAPDH TaqMan gene expression kits and superscript IV reverse transcription kit were obtained from Fisher Scientific (Waltham, MA).

\section{Equipment}

The AccuSkan GO microplate reader was procured from Thermo Fisher (Thermo Fisher Scientific, Finland) and the TRI-CARB1 1900CA liquid scintillation analyzer was obtained from Packard Instrument Company, Inc (Downers Grove, IL). 


\section{Cell lines}

NCI-H460, an NSCLC cell line, and mitoxantrone-selected ABCG2 overexpressing drugresistant NCI-H460/MX20 cells were selected for this study. NCI-H460/MX20 cell line was established by culturing the sensitive/parental NSCLC cell line, NCI-H460 with the anticancer drug, mitoxantrone up to a concentration of $20 \mathrm{nM}$ [52]. HEK293/pcDNA3.1 (human embryonic kidney cell line transfected with empty vector), HEK293 cells transfected with the ABCG2 cDNA, HEK293/R482 (wild-type) and HEK293/R482G and HEK293/R482T (2 variants) cells were grown in G418 (geneticin, an aminoglycoside antibiotic) at a concentration of $2 \mathrm{mg} / \mathrm{ml}$ following transfection of HEK293/pcDNA3.1 enclosed with full-length ABCG2 cDNA coding with arginine (R), glycine $(\mathrm{G})$ or threonine $(\mathrm{T})$ at position 482 [53]. NCI-H460/MX20 has characteristics similar to that in vivo but multiple factors that can cause MDR other than overexpression of the ABCG2 transporter [54] and the role of ABCG2-mediated resistance can be confirmed by the use of transfected cell lines, although these cells are non-cancerous. All the cell lines including SW620 (parental) and SW620/AD300 colon cancer cells (overexpressing ABCB1 transporter) were cultured in DMEM medium supplemented with $10 \%$ FBS and $1 \%$ penicillin and streptomycin, in 5\% $\mathrm{CO}_{2}$ at $37^{\circ} \mathrm{C}$. SW620/AD300 cells were established by culturing them in gradually increasing concentrations of doxorubicin. The HEK293/pcDNA3.1 cell line was transfected with the DNA coding for the ABCC1 transporter to generate the HEK293/ABCC1 cell line $[55,56]$. Cells were cultured as a monolayer and were maintained in regular drug-free medium for at least two weeks prior to conduct the experiments.

\section{MTT assay for cytotoxicity determination and the reversal experiments}

The MTT cytotoxicity assay was performed in a 96 well plate to determine the concentration of GS9973 to be used in experiments with the parental and drug-resistant cell lines. A seeding density of $4 \times 10^{3}$ cells/well was used for the entirety of cell lines. The absorbance was obtained using a spectrophotometer, set at $570 \mathrm{~nm}$ as previously described [57-60]. The concentrations at which around $85 \%$ of parental and resistant cells survived (i.e., 1 and $3 \mu \mathrm{M}$ ) were used for the reversal experiments.

For the reversal experiments, parental NCI-H460 and drug-resistant NCI-H460/MX20 cells were treated for $2 \mathrm{~h}$ with 1 and $3 \mu \mathrm{M}$ of GS-9973, $3 \mu \mathrm{M}$ of Ko143, a known ABCG2 inhibitor. Following incubation, an anticancer agent, mitoxantrone, doxorubicin, cisplatin, or vincristine, was added at different concentrations $(20 \mu \mathrm{l} /$ well $)$ into the designated wells. The MTT assay was performed after $72 \mathrm{~h}$ of incubation by recording the absorbance at 570 $\mathrm{nm}$. The resistance folds were computed by dividing the $\mathrm{IC}_{50}$ value in resistant cells, with or without the drug (GS-9973 or Ko143), by the $\mathrm{IC}_{50}$ value of the parental cells.

\section{[ $\left.{ }^{3} \mathrm{H}\right]$ - Mitoxantrone accumulation and efflux assay}

The intracellular accumulation and efflux activity of the ABCG2 transporter is estimated by incubating NCI-H460 and NCI-H460/MX20 cancer cells in the presence or absence of 1 and $3 \mu \mathrm{M}$ of GS-9973 or Ko143 $(3 \mu \mathrm{M})$ for $2 \mathrm{~h}$ at $37^{\circ} \mathrm{C}$ followed by treating with $0.01 \mu \mathrm{M}$ of $\left[{ }^{3} \mathrm{H}\right]$-mitoxantrone (at 0,30 , 60 and $120 \mathrm{~min}$ ) for $2 \mathrm{~h}$ as previously described [61]. The radioactivity was quantified using a scintillation counter.

\section{Western blot analysis}

Western blot analysis was carried out to detect the expression level of ABCG2 protein. NCI-H460 and NCI-H460/MX20 cells were cultured and seeded in T25 flasks ( 1 million cells/flask) and the next day, 3 $\mu \mathrm{M}$ of GS-9973 was added and incubated for different time points, 24, 48 and $72 \mathrm{~h}$. Cell lysates were prepared by adding lysis buffer $(25 \mathrm{mM}$ Tris- $\mathrm{HCl}(\mathrm{pH}$ 7.6), $150 \mathrm{mM} \mathrm{NaCl}, 1 \%$ Triton $\mathrm{X}-100,1 \%$ sodium deoxycholate, $0.1 \%$ SDS) to cells overexpressing ABCG2. The ABCG2 protein expression assay was conducted using Western blotting as previously described [62]. The samples were incubated with primary antibodies, ABCG2 (D5V2K) and GAPDH (D16H1) $(1: 1000)$ overnight at $4^{\circ} \mathrm{C}$ and then incubated with horse radish peroxidase-conjugated secondary antibody (7074S) (1:1000) for $2 \mathrm{~h}$ at room temperature. The reaction was visualized by enhanced chemiluminescence detection reagents (Amersham, $\mathrm{NJ})$ using the manufacturer's protocol.

\section{mRNA expression}

NCI-H460 and NCI-H460/MX20 cancer cells were incubated with $3 \mu \mathrm{M}$ of GS-9973 for 24,48 and 72 $\mathrm{h}$ and total RNA was extracted using the RNA extraction trizol reagent as previously described [63]. RNA was quantified using Nanodrop and RNA samples with an A260/280 ratio in the range of 1.8 to 2.0 were subjected to reverse transcription and the cDNAs formed (by superscript IV reverse transcription kit) were used for quantitative PCR. This analysis was performed using the ABCG2 and GAPDH TaqMan gene expression assay kits. The PCR data were quantitated using the $\Delta \Delta \mathrm{Ct}$ method and presented as relative - fold of mRNA expression. 


\section{Immunofluorescence}

Immunofluorescence assay was performed to evaluate whether the reversal activity of GS-9973 was involved in the subcellular localization of the ABCG2 membrane protein. For the immunofluorescence analysis, the parental and the drug-resistant cells were seeded in a 24 well plate at a density of 10,000 cells/well and treated with or without the vehicle or 3 $\mu \mathrm{M}$ of GS-9973 for different time points, 24, 48, and 72 h. Briefly, washing was done thrice with PBS, followed by fixing for $15 \mathrm{~min}$ in $4 \%$ paraformaldehyde, and permeabilized using $0.1 \%$ Triton X-100 for $15 \mathrm{~min}$ and subsequently blocking with $6 \%$ BSA. The ABCG2 transporter was distinguished by an anti-ABCG2 monoclonal antibody and then accompanied by Alexa Fluor 488 conjugated secondary antibody. Later, nuclei were counterstained with DAPI. The images were taken using an EVOS FL Autofluorescence microscope (Thermo Scientific, Waltham, MA). The study was conducted independently in triplicates.

\section{ATPase assay}

The ABCG2 ATPase activity was carried out using PREDEASY ATPase Kits (TEBU-BIOnv, Boechout, Belgium) as mentioned previously [64]. For the ATPase assay, $10 \mu \mathrm{g}$ membrane with ABCG2 was incubated in the assay buffer. Then the membrane vesicles were incubated in GS-9973 for $3 \mathrm{~min}$. An addition of $5 \mathrm{mM}$ Mg-ATP activated the ATP hydrolysis. The reaction was terminated by adding $5 \%$ SDS solution after incubated for $20 \mathrm{~min}$ at $37^{\circ} \mathrm{C}$. The inorganic phosphate (Pi) was measured at $880 \mathrm{~nm}$ using a spectrophotometer.

\section{Molecular docking of GS-9973 with the human ABCG2 model}

Docking experiments were performed on a Mac Pro 6-core Intel Xenon E5 processor with Macintosh Operating System (OS Sierra) using the Maestro v12. 3. 012 software (Schrödinger, LLC, New York, NY, USA, 2019) software. Lig-prep was used for GS-9973 ligand preparation [65]. The human model of ABCG2 was imported from the Protein data bank. Protein Preparation Wizard was used for protein preparation. The grid was generated by selecting residues at $20 \AA$ length from bound inhibitors in the protein $(6 \mathrm{ETI})$ [66]. The residues selected were: 570, 571, 578, 624, 628, 631, 632, 635, 636, 639, 640. Extra Precision docking was performed with a maximum of 10 poses [67].

\section{HPLC analysis}

NCI-H460 and NCI-H460/MX20 cells were seeded in a 6-well-plate at a density of $2 \times 10^{5}$ cells per well and cultured for 2 days, media was replaced with plain media (DMEM without FBS), and was treated with $10 \mu \mathrm{M}$ of GS-9973 for $2 \mathrm{~h}$. Washing was done with PBS and $0.5 \%$ Sodium dodecyl sulfate and acetonitrile were added to the plate to lyse the cells for the extraction of the drug. The lysates were obtained and centrifuged at a speed of $14,000 \mathrm{rpm}$ for $10 \mathrm{~min}$ and the supernatant formed was used to measure the intracellular concentration of GS-9973 by HPLC. HPLC was performed using the Agilent Technologies instrument (Prep218 pump and Prostar 325 detector) and monitored using a dual-wavelength detector (250 and $258 \mathrm{~nm}$ ). The eluents used were, water (Solvent A) and acetonitrile (Solvent B), both solvents supplemented with $0.1 \%$ formic acid to maintain buffer capacity. Purification was done using a C8 analytical column (Agilent Eclipse Plus 3.5 mm, 4.6 X $150 \mathrm{~mm}$ ). Flow rate: $1 \mathrm{ml} / \mathrm{min}$. Isocratic solvent system: 60:40 water: acetonitrile and the run time was $15 \mathrm{~min}$. The standard curve was plotted using different concentrations of GS-9973 were used (8 $\mathrm{ng} / \mathrm{ml}, 4 \mathrm{ng} / \mathrm{ml}, 2 \mathrm{ng} / \mathrm{ml}, 1 \mathrm{ng} / \mathrm{ml}$ ) against area under the curve (AUC).

\section{Statistical analysis}

All experiments were repeated in triplicates and the data was analyzed using GraphPad Prism (version 8 ). The a priori significance level was $p<0.05$ and the results were evaluated with one-way or two-way ANOVA and post hoc analysis was conducted using Dunnett's post hoc test.

\section{Results}

\section{GS-9973 sensitizes ABCG2 overexpressing cells to anticancer drugs}

The MTT assay data indicated that the nontoxic concentrations of GS-9973 (concentration at which $85 \%$ of cells survive) were 1 and $3 \mu \mathrm{M}$ (Figure 1A, 2A, $3 \mathrm{C}$ ) and 1 and $10 \mu \mathrm{M}$ (Figure 3A). These concentrations of GS-9973 markedly increased the cytotoxicity of mitoxantrone (Figure 1B) and doxorubicin in the drug-resistant cell line, NCI-H460/ MX20 (Figure 1C) and in the transfected resistant cell lines, HEK293/R482 (wild-type), HEK293/R482G and HEK293/R482T (2 variants) to mitoxantrone (Figure 2B) and doxorubicin (Figure 2C). The resistance-fold values were reversed in NCI-H460/MX20 cancer cells treated with mitoxantrone (from 73.3- to 13.9-fold resistance), and doxorubicin (155.7 - to 11.1-fold resistance) individually (Table 1 ) in the presence of 3 $\mu \mathrm{M}$ of GS-9973. Besides, $3 \mu \mathrm{M}$ of GS-9973 also reversed the drug resistance to the anticancer drugs, mitoxantrone and doxorubicin in the cells transfected with ABCG2 (Table 2). The reversal activity of $3 \mu \mathrm{M}$ of 
GS-9973 for the ABCG2 transporter was compared to the same concentration of Ko143 [68]. Moreover, GS-9973 did not change the efficacy of drugs, mitoxantrone and doxorubicin in the NCI-H460 parental non-resistant cell line. Also, GS-9973, at 3 $\mu \mathrm{M}$, could not modify the efficacy of the anticancer drug, cisplatin, (not an ABCG2 substrate) [69] (Figure $1 \mathrm{D}$ and Figure 2D). Finally, $10 \mu \mathrm{M}$ of GS-9973 did not remarkably reverse the drug resistance of 1) SW620/AD300 colon cancer cells, which have high expression of the $\mathrm{ABCB} 1$ transporter, to doxorubicin (Figure 3B), 2) $3 \mu \mathrm{M}$ of GS-9973 did not modify the efficacy of the anticancer drug, vincristine in HEK293/ABCC1 cells, which overexpress the ABCC1 transporter (Figure 3D). Overall, our results show that GS-9973 reverses the anticancer drug resistance to mitoxantrone and doxorubicin in wild-type and mutant-type cancer cell lines that overexpress the ABCG2 transporter.

\section{GS-9973 significantly decreases the efflux of $\left[{ }^{3} \mathrm{H}\right]$-mitoxantrone in $\mathrm{NCl}-\mathrm{H} 460 / \mathrm{MX} 20$ cancer cells}

To figure out the mechanism by which GS-9973 reverses drug resistance, the accumulation and efflux assay was accomplished using radioactive tritium labeled $\left[{ }^{3} \mathrm{H}\right]$-mitoxantrone in the sensitive cell line, NCI-H460 and its mitoxantrone-resistant NSCLC cell line, NCI-H460/MX20. The accumulation of $\left[{ }^{3} \mathrm{H}\right]$-mitoxantrone in the mitoxantrone-resistant NCI-H460/MX20 cancer cells was substantially low compared to the parental cancer cells. The accumulation of $\left[{ }^{3} \mathrm{H}\right]$-mitoxantrone in the resistant cell line, NCI-H460/MX20 was significantly increased after incubation with $3 \mu \mathrm{M}$ of GS-9973 compared to vehicle. The treatment of parental cells with $3 \mu \mathrm{M}$ of GS-9973 has not shown any remarkable increase in the accumulation of $\left[{ }^{3} \mathrm{H}\right]$-mitoxantrone (Figure $4 \mathrm{D}$ ). These outcomes show that GS-9973 enhances the level of $\left[{ }^{3} \mathrm{H}\right]$-mitoxantrone in NCI-H460/MX20 cells compared to vehicle.

Table 1. The effect of GS-9973 on reversal of ABCG2 mediated MDR in the drug-resistant cell lines

\begin{tabular}{lllll}
\hline Cell lines & NCIH460 & \multicolumn{3}{l}{ NCIH460/MX20 } \\
\hline Compounds & $\mathrm{IC}_{50} \pm \mathrm{SD}(\mu \mathrm{M})$ & $\mathrm{FR}$ & $\mathrm{IC}_{50} \pm \mathrm{SD}(\mu \mathrm{M})$ & FR \\
\hline Mitoxantrone & $0.115 \pm 0.013$ & {$[1.0]$} & $7.352 \pm 0.843$ & {$[73.3]$} \\
+ GS-9973 $(1 \mu \mathrm{M})$ & $0.123 \pm 0.021$ & {$[1.1]$} & $3.612 \pm 0.433$ & {$[36.1]$} \\
+ GS-9973 $(3 \mu \mathrm{M})$ & $0.151 \pm 0.025$ & {$[1.3]$} & $1.395 \pm 0.051$ & {$[13.9]$} \\
+Ko $143(3 \mu \mathrm{M})$ & $0.101 \pm 0.015$ & {$[0.9]$} & $1.251 \pm 0.015$ & {$[12.5]$} \\
Doxorubicin & $0.108 \pm 0.015$ & {$[1.0]$} & $15.579 \pm 1.835$ & {$[155.7]$} \\
+ GS-9973 $(1 \mu \mathrm{M})$ & $0.115 \pm 0.026$ & {$[1.2]$} & $4.363 \pm 0.523$ & {$[43.6]$} \\
+ GS-9973 $(3 \mu \mathrm{M})$ & $0.135 \pm 0.02$ & {$[1.7]$} & $1.119 \pm 2.3$ & {$[11.1]$} \\
+Ko 143 $(3 \mu \mathrm{M})$ & $0.09 \pm 0.011$ & {$[0.7]$} & $1.982 \pm 0.277$ & {$[19.9]$} \\
Cisplatin & $144.959 \pm 22.426$ & {$[1.0]$} & $164.845 \pm 23.119$ & {$[1.3]$} \\
+ GS-9973 $(1 \mu \mathrm{M})$ & $149.259 \pm 23.131$ & {$[1.1]$} & $143.985 \pm 27.406$ & {$[1.1]$} \\
+ GS-9973 $(3 \mu \mathrm{M})$ & $153.98 \pm 19.123$ & {$[1.0]$} & $156.876 \pm 21.99$ & {$[1.1]$} \\
+Ko 143 $(3 \mu \mathrm{M})$ & $156.51 \pm 15.951$ & {$[1.0]$} & $165.785 \pm 19.335$ & {$[1.3]$} \\
\hline
\end{tabular}

$\mu \mathrm{M}-$ Micromole.

Values in tables indicate least three independent experiments performed in triplicates.

$\mathrm{IC}_{50}$ : concentration of the drug that is required for inhibition of cell survival by $50 \%$ $($ mean $\pm \mathrm{SD})$

FR: Resistance fold was calculated by dividing the $\mathrm{IC}_{50}$ values of anticancer drugs in drug-resistant cells in the presence or absence of inhibitor by the $\mathrm{IC}_{50}$ of parental cells without inhibitor.
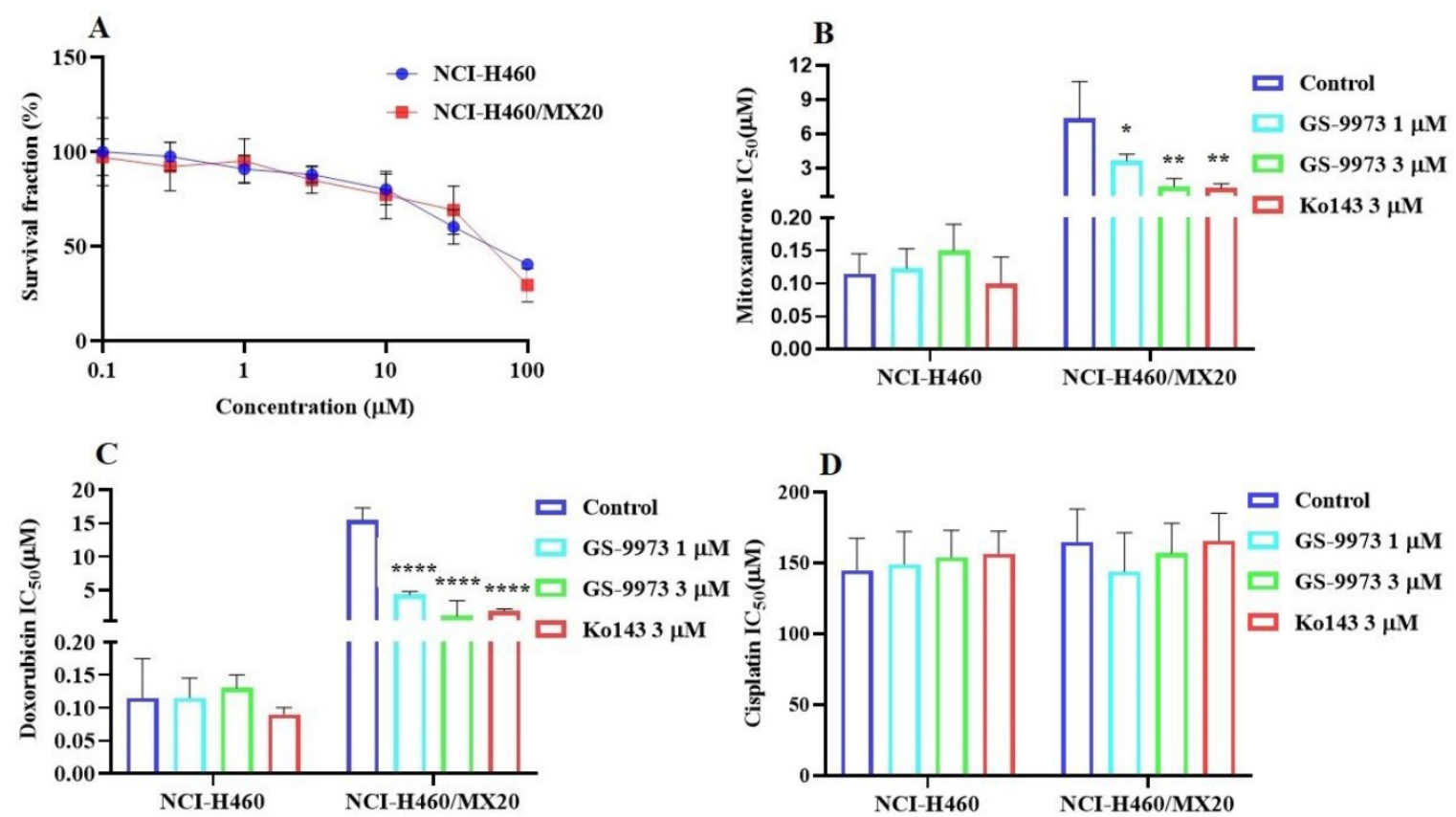

Figure 1. The effect of GS-9973 in parental NCI-H460 and ABCG2-overepxressing NCI-H460/MX20 cancer cell lines. (A) The survival fraction (\%) was determined following incubation with $0.1-100 \mu \mathrm{M}$ of GS-9973 for $72 \mathrm{~h}$ in NCl-H460 (blue) and $\mathrm{NCl}-\mathrm{H} 460 / \mathrm{MX20}$ (red) cell lines and IC 50 values of (B) mitoxantrone, (C) doxorubicin and (D) cisplatin in parental NCl-H460 and drug-selected ABCG2 overexpressing NCl-H460/MX20 cancer cells with or without GS-9973. All data are shown as mean \pm SD and represents three independent experiments. ${ }^{*} p \leq 0.05$, $* * p \leq 0.01$ and ${ }^{* * * * *} p<0.0001$ compared to the control group. 

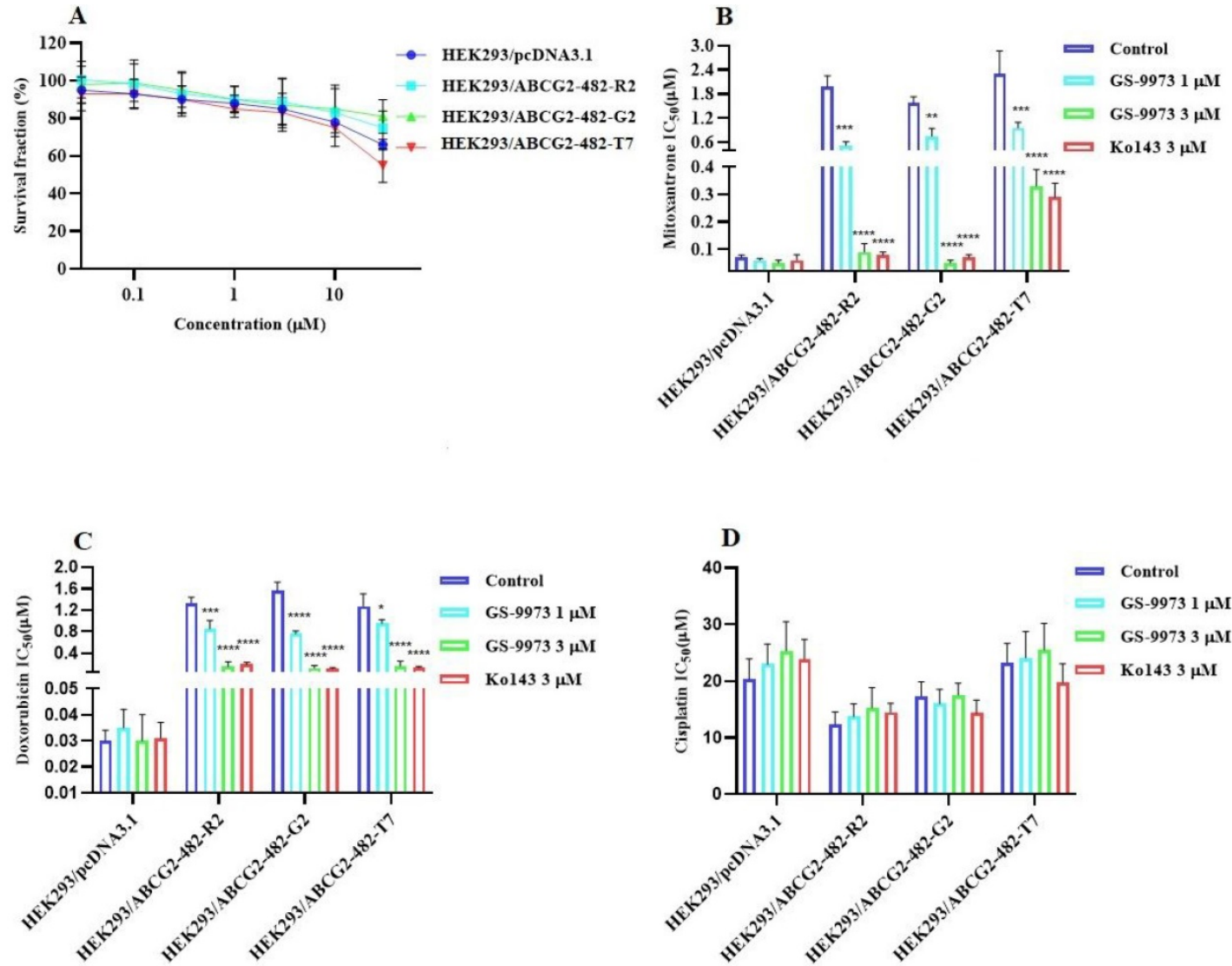

Figure 2. The effect of GS-9973 in HEK293 cells transfected with the gene coding for the ABCG2 transporter. (A) The survival fraction (\%) for HEK293/pcDNA3.1 (empty DNA vector control), HEK293/ABCG2-482-R2, HEK293/ABCG2-482-G2 and HEK293/ABCG2-482-T7 cell lines was determined following incubation with 0.03-30 $\mu \mathrm{M}$ of GS-9973 for $72 \mathrm{~h}$. The IC 50 values of (B) mitoxantrone, (C) doxorubicin, and (D) cisplatin in HEK293/pcDNA3.1 (empty DNA vector control), HEK293/ABCG2-482-R2, HEK293/ABCG2-482-G2 and HEK293/ABCG2-482-T7 cell lines. Data are exhibited as mean \pm SD and acquired from at least three independent experiments. $* p \leq 0.05, * * p \leq 0.01, * * * p<0.001$ and $* * * * p<0.0001$ compared to the control group.
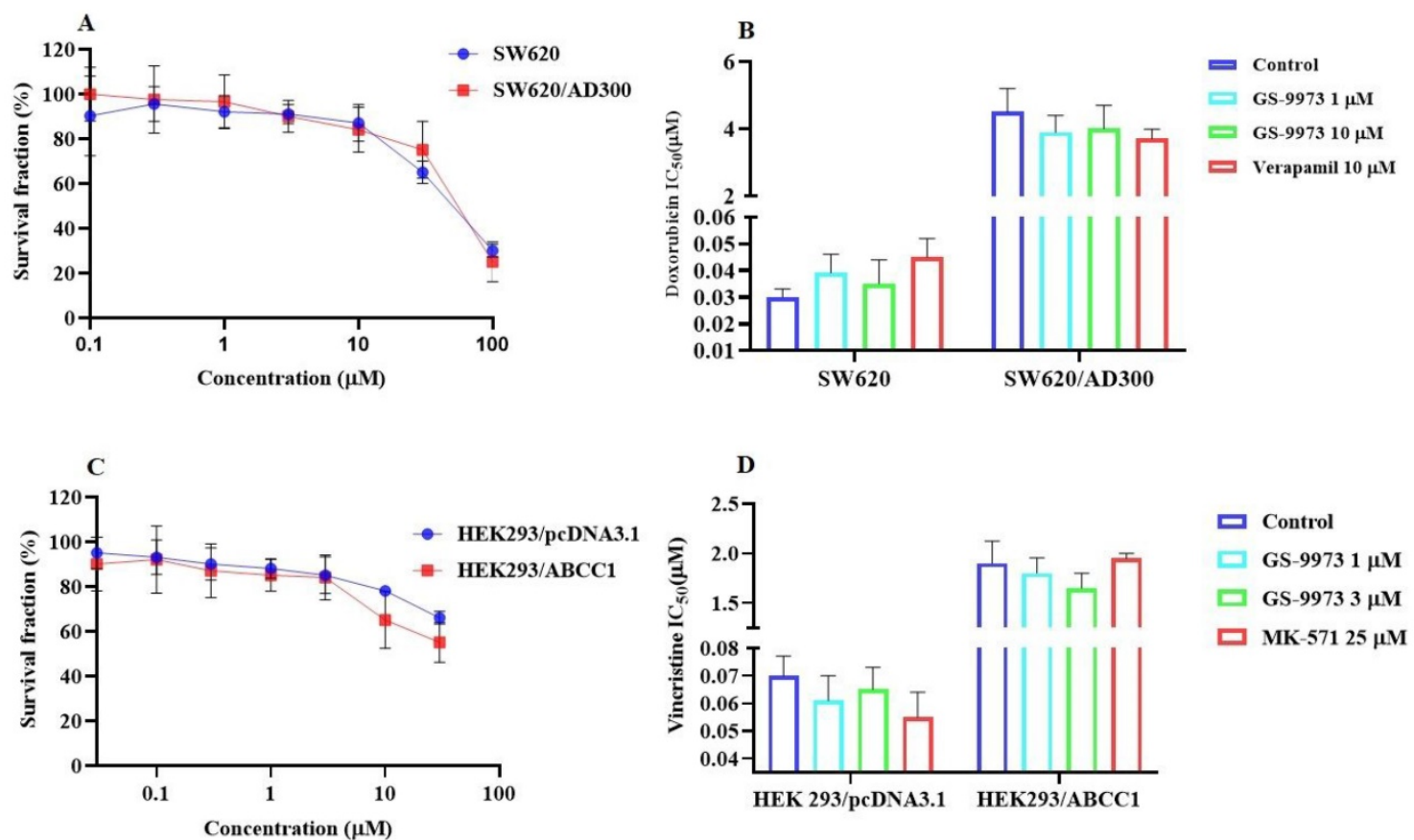

Figure 3. The effect of GS-9973 in SW620 parental, ABCB1-overexpressing SW620/AD300 colon cancer cells and HEK293/pcDNA3.1 parental and HEK293/ABCC1 transfected cells. (A) The survival fraction (\%) for the SW620 parental and SW620/AD300 colon cancer cell lines were determined following incubation with 0-100 $\mu$ M of GS-9973 for $72 \mathrm{~h}$. (B) The IC50 values of doxorubicin in the presence of vehicle (Control), GS-9973 (1 or $10 \mu \mathrm{M})$ or verapamil $(10 \mu \mathrm{M})$ for $72 \mathrm{~h}$ in SW620 parental and SW620/AD300 colon cancer cells. (C) The survival fraction (\%) for the HEK293/pcDNA3.1 (empty DNA vector control) and HEK293/ABCC1 (transfected with the DNA coding for the $A B C C 1$ transporter) cells were determined following incubation with 0-30 $\mu \mathrm{M}$ of GS-9973 for $72 \mathrm{~h}$. (D) The IC50 values of vincristine in the presence of vehicle (Control), GS-9973 (1 or $3 \mu \mathrm{M})$ or MK-571 $(25 \mu \mathrm{M})$ for $72 \mathrm{~h}$ in HEK293/pCDNA3.1 and HEK293/ABCCl cells. The points with error bars represent the mean \pm SD of independent determinations in triplicate. The figures are representative of three independent experiments. 
<smiles>c1cn2cc(-c3ccc4cn[nH]c4c3)nc(Nc3ccc(N4CCOCC4)cc3)c2n1</smiles>
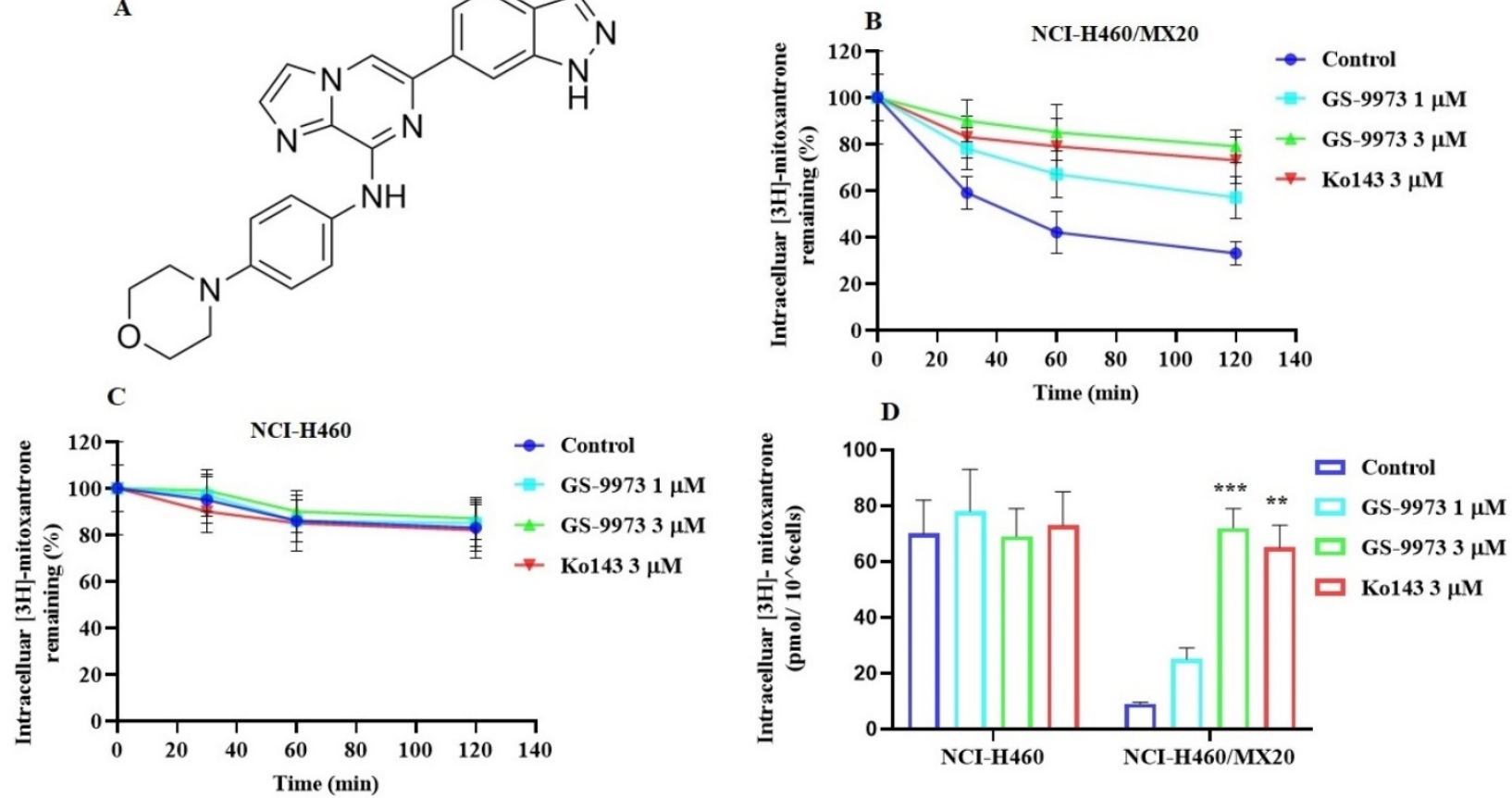

Figure 4. (A) The chemical structure of GS-9973. (B) The effect of the incubation of vehicle (Control), GS-9973 (1 or $3 \mu M)$ or Kol43 $(3 \mu M)$ for 30,60 or 120 min on the intracellular level of the $A B C G 2$ transporter substrate, $\left[{ }^{3} \mathrm{H}\right]-$ mitoxantrone from $\mathrm{NCl}-\mathrm{H} 460 / \mathrm{MX} 20$ cancer cells overexpressing the $A B C G 2$ transporter. (C) The effect of the

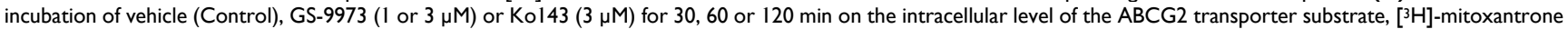
from NCl-H460 parental cancer cells. (D) The effect of vehicle (Control), GS-9973 (1 or $3 \mu \mathrm{M})$ or Kol43 $(3 \mu \mathrm{M})$ on the intracellular accumulation of [ $\left.{ }^{3} \mathrm{H}\right]$-mitoxantrone in $\mathrm{NCl}-\mathrm{H} 460$ and NCl-H460/MX20 cancer cells. The columns are the mean of triplicate determinations; the error bars represent the SD. $* * p \leq 0.01$ and $* * * p<0.001$ compared with control group.

Table 2. The effect of GS-9973 on reversal of ABCG2 mediated MDR in the transfected cell lines

\begin{tabular}{|c|c|c|c|c|c|c|c|c|}
\hline Cell lines & HEK293/pcDN & JA3.1 & HEK293/R2 & & HEK293/G2 & & HEK293/T7 & \\
\hline Compounds & $\mathrm{IC}_{50} \pm \mathrm{SD}(\mu \mathrm{M})$ & FR & $\mathrm{IC}_{50} \pm \mathrm{SD}(\mu \mathrm{M})$ & FR & $\mathrm{IC}_{50} \pm \mathrm{SD}(\mu \mathrm{M})$ & FR & $\mathrm{IC}_{50} \pm \mathrm{SD}(\mu \mathrm{M})$ & FR \\
\hline Mitoxantrone & $0.07 \pm 0.009$ & [1.0] & $1.98 \pm 0.27$ & [28.2] & $1.57 \pm 0.16$ & [22.5] & $2.3 \pm 0.57$ & {$[32.8]$} \\
\hline + GS-9973 $(1 \mu \mathrm{M})$ & $0.06 \pm 0.006$ & {$[1.25]$} & $0.52 \pm 0.09$ & [7.3] & $0.75 \pm 0.19$ & {$[10.7]$} & $0.957 \pm 0.14$ & [12.7] \\
\hline +GS-9973 (3 $\mu \mathrm{M})$ & $0.05 \pm 0.01$ & {$[0.94]$} & $0.09 \pm 0.03$ & [1.3] & $0.05 \pm 0.009$ & {$[0.7]$} & $0.33 \pm 0.06$ & [4.3] \\
\hline$+\mathrm{Ko} 143(3 \mu \mathrm{M})$ & $0.06 \pm 0.02$ & {$[1.26]$} & $0.08 \pm 0.01$ & [1.1] & $0.07 \pm 0.01$ & [1.0] & $0.29 \pm 0.05$ & [4.1] \\
\hline Doxorubicin & $0.03 \pm 0.004$ & [1.0] & $1.33 \pm 0.11$ & [43.3] & $1.56 \pm 0.16$ & {$[52.2]$} & $1.27 \pm 0.23$ & [40.1] \\
\hline +GS-9973 (1 $\mu \mathrm{M})$ & $0.035 \pm 0.007$ & [0.8] & $0.85 \pm 0.157$ & [18.3] & $0.76 \pm 0.05$ & [9.6] & $0.95 \pm 0.07$ & [19.0] \\
\hline +GS-9973 $(3 \mu \mathrm{M})$ & $0.03 \pm 0.01$ & [0.9] & $0.15 \pm 0.07$ & {$[5.0]$} & $0.12 \pm 0.02$ & [4.1] & $0.16 \pm 0.02$ & [5.3] \\
\hline$+\mathrm{Ko} 143(3 \mu \mathrm{M})$ & $0.031 \pm 0.006$ & [1.0] & $0.19 \pm 0.04$ & [6.3] & $0.11 \pm 0.02$ & [3.6] & $0.13 \pm 0.02$ & [4.3] \\
\hline Cisplatin & $20.33 \pm 3.66$ & [1.0] & $12.33 \pm 2.22$ & {$[0.9]$} & $17.348 \pm 2.57$ & {$[0.9]$} & $23.33 \pm 3.36$ & [1.1] \\
\hline +GS-9973 (1 $\mu \mathrm{M})$ & $22.99 \pm 3.55$ & [1.1] & $13.73 \pm 2.24$ & {$[0.9]$} & $15.99 \pm 2.56$ & [1.1] & $24.12 \pm 4.63$ & [1.1] \\
\hline +GS-9973 $(3 \mu \mathrm{M})$ & $25.35 \pm 5.12$ & [1.1] & $15.25 \pm 3.61$ & [1.0] & $17.55 \pm 2.11$ & {$[0.9]$} & $25.55 \pm 4.65$ & {$[1.0]$} \\
\hline +Ko143 $(3 \mu \mathrm{M})$ & $23.95 \pm 3.39$ & [1.1] & $14.52 \pm 1.57$ & [1.1] & $14.33 \pm 2.33$ & [1.0] & $19.79 \pm 3.30$ & [1.0] \\
\hline
\end{tabular}

$\mu \mathrm{M}$-Micromole.

Values in tables indicate least three independent experiments performed in triplicates.

$\mathrm{IC}_{50}$ : concentration of the drug that is required for inhibition of cell survival by $50 \%$ (mean $\pm \mathrm{SD}$ ).

FR: Resistance fold was calculated by dividing the $\mathrm{IC}_{50}$ values of anticancer drugs in transfected cells in the presence or absence of inhibitor by the $\mathrm{IC}_{50}$ of parental cells without inhibitor.

To determine if the rise in the level of $\left[{ }^{3} \mathrm{H}\right]$-mitoxantrone in MDR cells was due to GS-9973 preventing the ABCG2 transporter efflux activity, we measured $\left[{ }^{3} \mathrm{H}\right]$-mitoxantrone levels in the drug-resistant cells with or without GS-9973 at various time points. In the NCI-H460/MX20 cancer cells, intracellular accumulation of $\left[{ }^{3} \mathrm{H}\right]$-mitoxantrone were $59 \%, 42 \%$, and $33 \%$ that of NCI-H460 parental cancer cell line, at 30,60, and $120 \mathrm{~min}$, respectively, in the absence of GS-9973 treatment (Figure 4B), proving that the efflux of $\left[{ }^{3} \mathrm{H}\right]$-mitoxantrone was mediated by the ABCG2 transporter. The efflux of $\left[{ }^{3} \mathrm{H}\right]$-mitoxantrone was significantly reduced with GS-9973 at a concentration of $3 \mu \mathrm{M}$ thereby increasing the intracellular $\left[{ }^{3} \mathrm{H}\right]$-mitoxantrone level $(90 \%$ at 30 min, $85 \%$ at $60 \mathrm{~min}$, and $79 \%$ at $120 \mathrm{~min}$ (Figure 4B) The proportion of the decrease in the efflux of $\left[{ }^{3} \mathrm{H}\right]$-mitoxantrone by GS-9973 was comparable to that of $3 \mu \mathrm{M}$ of Ko143. intracellular concentration of $\left[{ }^{3} \mathrm{H}\right]$-mitoxantrone in the parental cancer cells was not notably changed by $3 \mu \mathrm{M}$ of GS-9973 in comparison with the cells incubated with the vehicle (Figure 4C). 

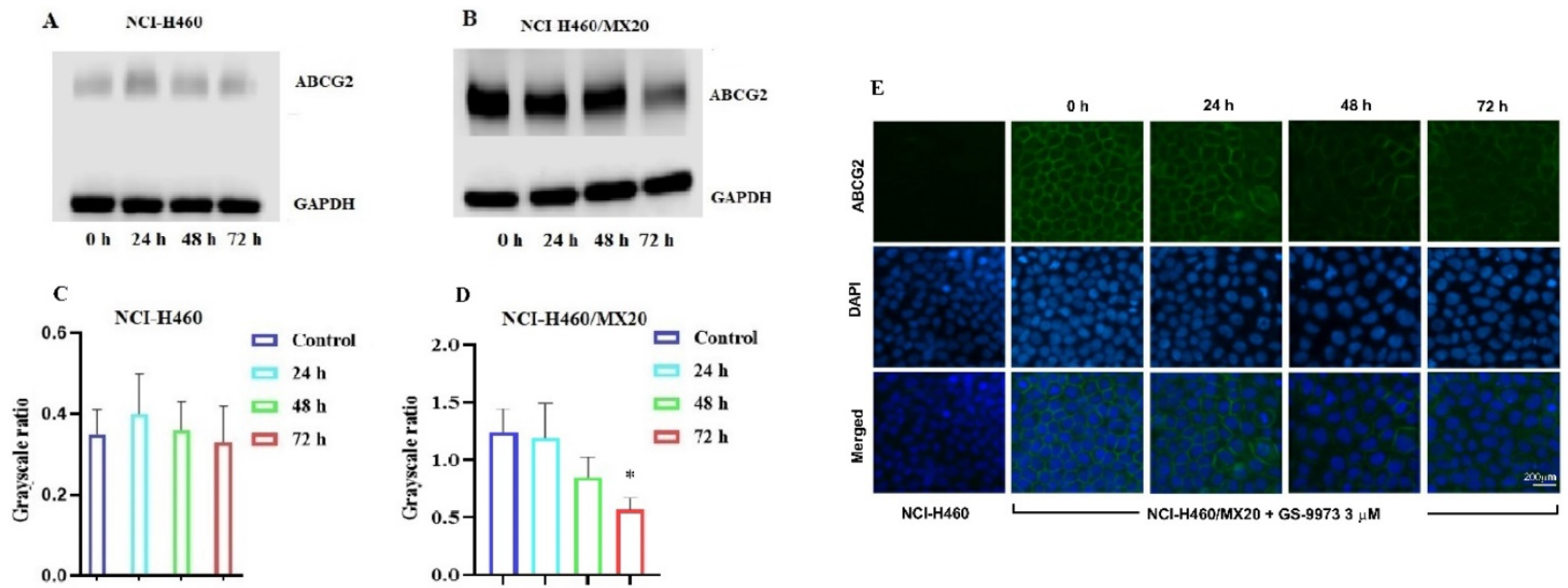

Figure 5. The effect of GS-9973 on the expression of the ABCG2 protein. Analysis of $\mathrm{ABCG} 2$ expression in (A) $\mathrm{NCl}-\mathrm{H} 460$ and $(\mathbf{B}) \mathrm{NCl}-\mathrm{H} 460 / \mathrm{MX} 20$ cancer cells after the cells were incubated with $6 \mu \mathrm{M}$ of GS-9973 for 24, 48 and $72 \mathrm{~h}$. Relative quantification of the effect of GS-9973 on ABCG2 in (C) NCl-H460 and (D) NCl-H460/MX20 cells. ABCG2 expression levels were normalized to GAPDH. Equal amounts of total cell lysates were employed for each sample and Western blot analysis was performed. $* p \leq 0.05$ compared with control group. (E) The effect of GS-9973 on the expression and localization of ABCG2 using immunofluorescence. The effect of incubation of NCI-H460 and $\mathrm{NCl}-\mathrm{H} 460 / \mathrm{MX} 20$ cancer cells with $3 \mu \mathrm{M}$ of GS-9973 for 0, 24, 48 and $72 \mathrm{~h}$. The green color represents the presence of the ABCG2 transporter, and the blue color represents the nucleus.

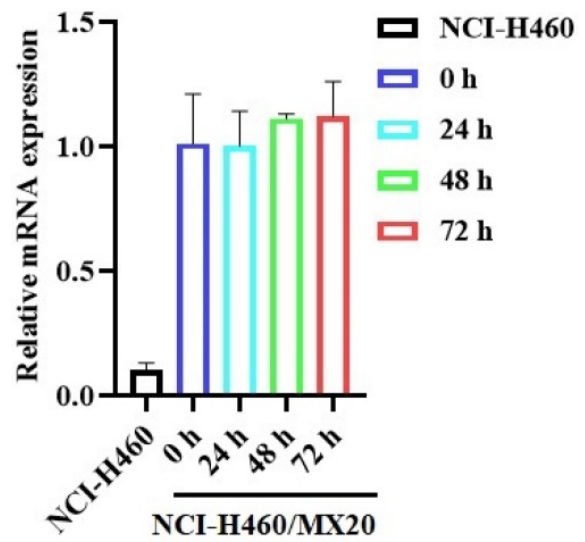

Figure 6. The effect of GS-9973 on ABCG2 mRNA expression. After incubation of $\mathrm{NCl}-\mathrm{H} 460$ and $\mathrm{NCl}-\mathrm{H} 460 / \mathrm{MX} 20$ cancer cells with $3 \mu \mathrm{M}$ of $\mathrm{GS}-9973$ for $0,24,48$ and $72 \mathrm{~h}, \mathrm{RT}-\mathrm{PCR}$ was conducted to determine the expression of ABCG2 mRNA.

In conclusion, our results indicated that GS-9973 significantly enhanced the $\left[{ }^{3} \mathrm{H}\right]$-mitoxantrone accumulation in NCI-H460/MX20 cancer cells by blocking the pumping out function of the ABCG2 transporter.

\section{The effect of GS-9973 on the expression of ABCG2}

The reversal effect of GS-9973 on the ABCG2-mediated MDR can be due to the inhibition of the efflux function of ABCG2 and/or the downregulation of the ABCG2 transporter expression. Therefore, Western blot analysis was performed to determine the GS-9973 mechanism on the ABCG2 protein expression in the parental and resistant cancer cells. The treatment of NCI-H460/MX20 cancer cells with $3 \mu \mathrm{M}$ of GS-9973 for $72 \mathrm{~h}$ significantly inhibited the ABCG2 protein expression level compared to the untreated cells (Figure 5B and D). These results combine with the efflux of $\left[{ }^{3} \mathrm{H}\right]$-mitoxantrone results, showed that the reversal action of GS-9973 in the ABCG2 overexpressed cancer cells was due to the inhibition of the ABCG2 protein expression and by blocking the transport function. The parental cell line, NCI-H460 has a very minimal expression of ABCG2 protein (Figure $5 \mathrm{~A}$ and $\mathrm{B}$ ) which further proves the selective action of GS-9973 on the ABCG2 overexpressing cell line. In addition, RT-PCR (quantitative real-time PCR) experiments indicated that the incubation of NCI-H460/MX20 cancer cells with $3 \mu \mathrm{M}$ of GS-9973 for $72 \mathrm{~h}$ did not change the level of ABCG2 mRNA expression (Figure 6).

\section{The effect of GS-9973 on the cellular localization of the ABCG2 transporter protein}

The reversal effect of GS-9973 in NCI-H460/MX20 cancer cells could be a change in the subcellular localization of ABCG2 from the cell membrane (i.e., the transporter would not be in the cell membrane, producing a decrease in drug efflux from the cells). Hence, an immunofluorescence assay was carried out to establish if GS-9973 affected the sub-cellular localization of the ABCG2 transporter from the cell surface to the cytoplasm. The incubation of the drug-resistant cells with $3 \mu \mathrm{M}$ of GS-9973 did not have any effect on the subcellular ABCG2 transporter localization from the cell membrane to the cytosol (Figure 5E).

\section{GS-9973 stimulates the activity of ABCG2 ATPase}

The drug efflux function of the ABCG2 transporter is linked to ATP hydrolysis and can be 
stimulated or inhibited by ABCG2 substrates [70]. To further assess the effect of GS-9973 on ABCG2 ATPase activity, we measured the ABCG2-mediated ATP hydrolysis after incubation with different concentrations of GS-9973 (0-40 $\mu \mathrm{M})$. According to the result, GS-9973 showed dose-dependent stimulation of ABCG2 ATPase activity and it achieved a maximum of $137.7 \%$ of the basal activity of ABCG2 ATPase (Figure 7). The stimulation effect of GS-9973 attained $50 \%$ maximal $\left(\mathrm{EC}_{50}\right)$ at $0.42 \mu \mathrm{M}$.

\section{The docking simulation of GS-9973 in the drug-binding pocket of the human ABCG2 protein}

The previously established human ABCG2 cryoEM structure model (PDB code: 6VXI) was employed for docking analysis. Induced-fit docking analysis was performed to stimulate interactions between GS-9973 and human ABCG2. The best-docked pose of GS-9973 had a Glide score of $-10.226 \mathrm{kcal} \mathrm{mol}^{-1}$, which indicates a better binding affinity in the ABCG2 drug-binding pocket. Figure 8 shows the docking pose and interaction between GS-9973 and ABCG2 protein. It depicts $\pi-\pi$ interaction between Phe439 and the phenyl adjacent to the imidazole ring and $\mathrm{H}$ - bonding is seen between the sidechain of Thr435 and nitrogen of imidazole ring of GS-9973.

\section{HPLC analysis}

The retention time $\left(t_{R}\right)$ of GS-9973 was first determined. The $t_{R}$ was found to be 5.3 min under the specified conditions (Figure 9B a). A standard curve was plotted. The samples collected from NCI-H460 and NCI-H460/MX20 were then injected, and the AUC was recorded (Figure $9 \mathrm{~B} \mathrm{~b}$ and $\mathrm{c}$ ), the drug concentration was calculated by using the equation from the standard curve. Each of the experiment was carried out in triplicates and the data were plotted using GraphPad prism. The HPLC data indicates that there is no remarkable difference in the intracellular accumulation of GS-9973 in NCI-H460 and NCI-H460/MX20 cells (Figure 9A).

\section{Discussion}

GS-9973 is reported to be a potent and competitive inhibitor of Syk [49]. Syk is involved in the signaling pathways in B cells, neutrophils, and mast cells [71], hence, GS-9973 has a promising role in various immune, cancer and inflammation-related disorders [72]. It is currently under clinical trial for the treatment for CLL in combination with idelalisib, a PI3K inhibitor [73]. In this study, experiments are conducted to figure out the MDR reversal effect of GS-9973 in the drug-resistant cell line, NCI-H460/ MX20 that overexpress the ABCG2 transporter and mechanisms mediating the reversal activity of GS-9973 to overcome MDR. From the cytotoxicity studies, 1 and $3 \mu \mathrm{M}$ of GS-9973 were used for the reversal experiments in the ABCG2 overexpressing cell line as the cell survival fraction was around $85 \%$ after $72 \mathrm{~h}$ incubation in both the NCI-H460 parental and resistant NCI-H460/MX20 cancer cells. As shown before, the anticancer efficacy of mitoxantrone and doxorubicin were notably decreased in the drugresistant cancer cells, in comparison with the parental NCI-H460 cells.

The two concentrations, 1 or $3 \mu \mathrm{M}$ of GS-9973 significantly magnified the anticancer efficacy (i.e., decreased drug resistance) of the ABCG2 substrates, mitoxantrone and doxorubicin in NCI-H460/MX20 cells, in comparison with the untreated cells. This data is consistent with the previous studies that

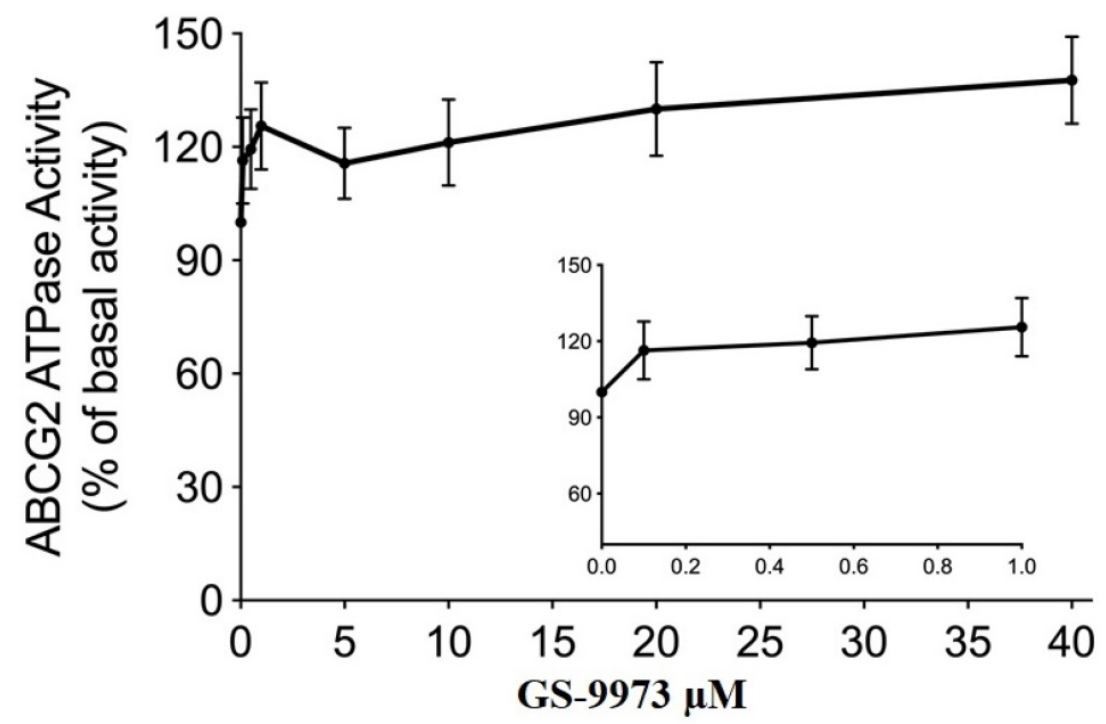

Figure 7. GS-9973 stimulated the ATPase activity of ABCG2. The graph illustrates the effect of $0-40 \mu M$ of GS-9973 on the ATPase activity of ABCG2. 
demonstrated the activity of various anticancer drugs in the sensitive cancer cells. In addition, the reversal effect of GS-9973 in NCI-H460/MX20 cells was the same as that of $3 \mu \mathrm{M}$ of Ko143, suggesting that GS-9973 has a significant reversal effect in ABCG2overexpressing cells. GS-9973 has some advantages over Ko143, as at high concentrations, Ko143 can acts as an inhibitor of both ABCB1 abs ABCC1 [74] which indicates the lack of selectivity towards ABCG2. Moreover, the efficacy of the anticancer drug, cisplatin was not altered significantly by $3 \mu \mathrm{M}$ of GS-9973 in the parental and resistant cancer cells proving that cisplatin is not an ABCG2 specific substrate which is consistent with the previous studies.

The occurrence of resistance to the anticancer drugs, mitoxantrone and doxorubicin are presented in HEK293 transfected cells with either the R482G or R482T mutations but not in the parental HEK293 cells. GS-9973 remarkably enhanced the efficacy of
$\mathbf{A}$

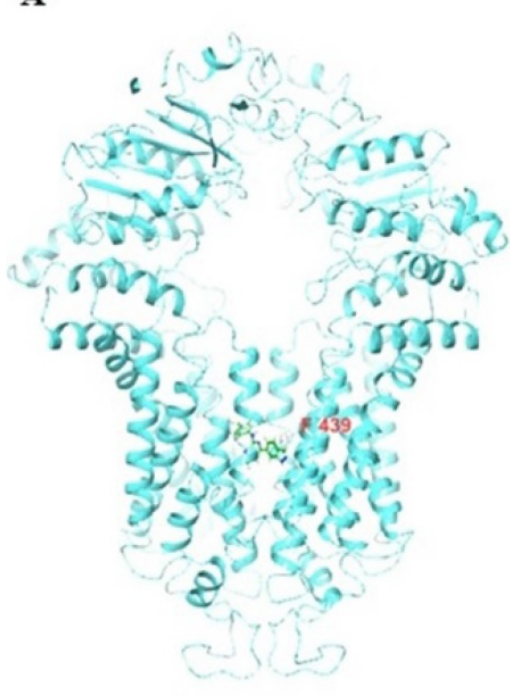

B

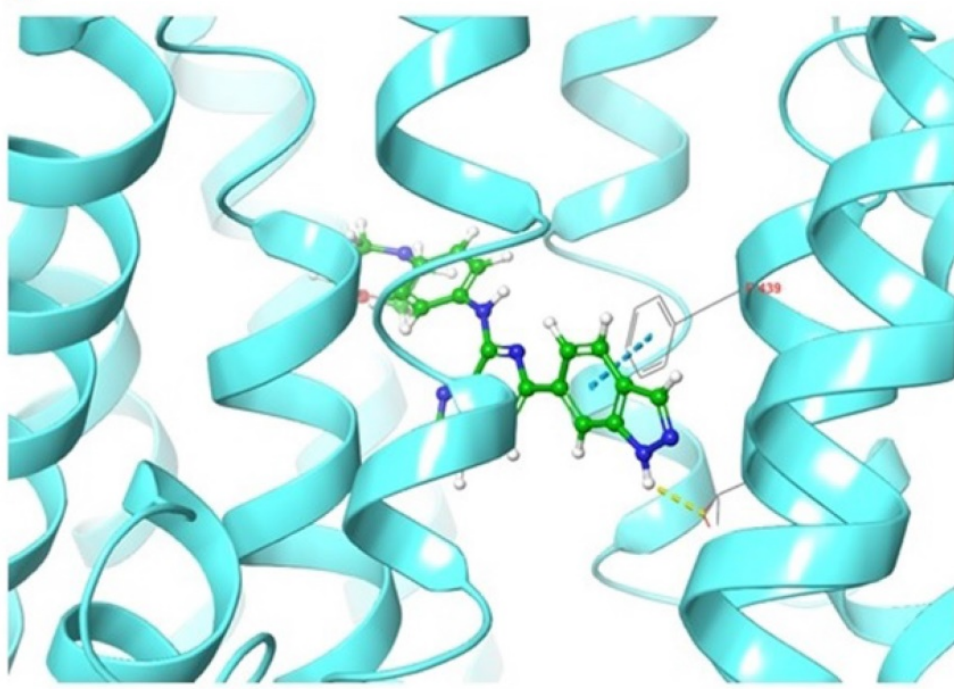

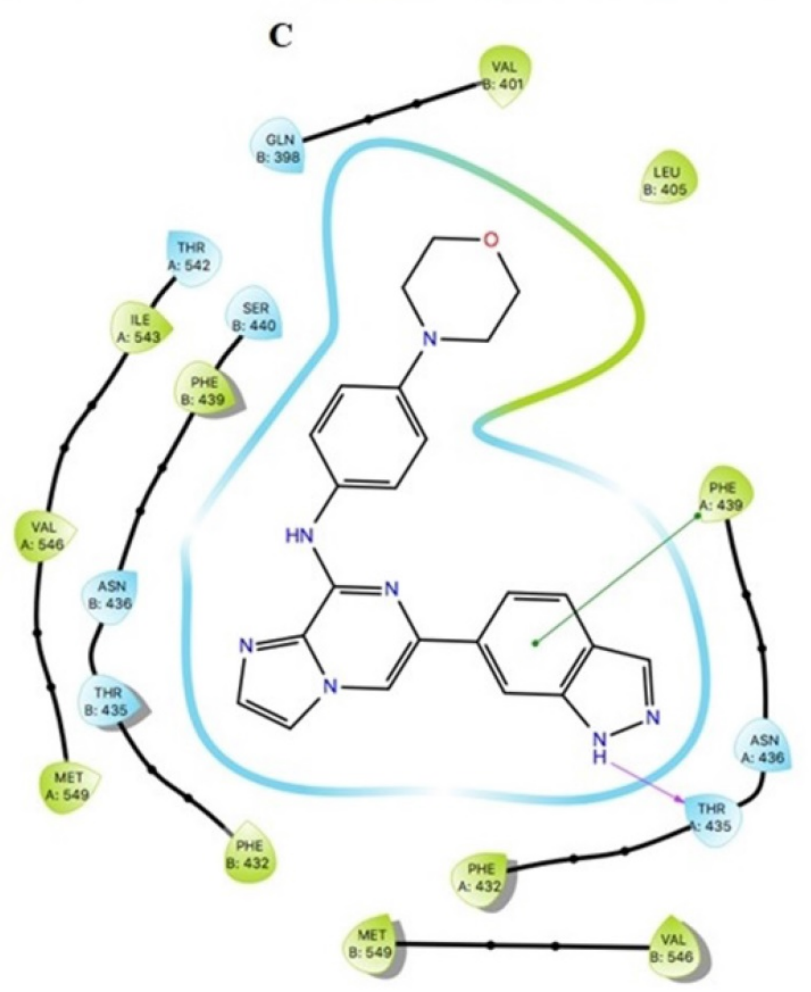

Figure 8. Molecular interaction of GS-9973 with the human ABCG2 model. (A) Whole ABCG2 protein with the docking site (highlighted with black box). (B) Docking pose of GS-9973 within the binding pocket of ABCG2. The protein is represented as sky blue colored ribbons. Amino acid residues are represented as follows: carbon in gray, hydrogen in white, nitrogen in blue and oxygen in red. The ligand is represented by the ball and stick model with carbon atoms are represented in green, oxygen in red nitrogen in blue and hydrogen in white. Blue dashes represent $\pi-\pi$ stacking interaction, yellow dashes represent the hydrogen bonding. (C) 2 -D ligand interaction between GS-9973 and ABCG2. Green indicates $\pi-\pi$ interaction with amino acid residues within $5 \AA$ of the ligand and the magenta arrow represents hydrogen bonding. 
mitoxantrone and doxorubicin in these ABCG2 transfected cell lines. It is established that the high expression of the ABCG2 gene in the transfected HEK293 cells is the only mechanism that confers the resistance to the chemotherapeutic drugs, mitoxantrone and doxorubicin, the results suggest that reversal efficacy of GS-9973 is primarily to its interaction with the ABCG2 transporter. Previous studies have shown that the wild and mutant forms of ABCG2 transporter are differentially affected by ABCG2 substrates. For example, wild type ABCG2 (R2) transporters are more sensitive to anthracycline but resistant to methotrexate, whereas the mutant forms, G2 and T7, of the ABCG2 transporter are more resistant to anthracyclines, but not to methotrexate $[75,76]$. It has been reported that many compounds vary in specificity regarding their inhibition of the ABCG2 transporter. For example, novobiocin only inhibits wild-type but GS-9973 inhibits both the wild-type and mutant forms of ABCG2 [77].

To determine whether the ABCG2 reversal activity of GS-9973 was selective, a reversal study was performed in the SW620/AD300 and HEK293/ ABCC1 cells which overexpress ABCB1 and ABCC1 transporter, respectively. Our results indicated that GS-9973, at 3 or $10 \mu \mathrm{M}$, did not affect the efficacy of vincristine and doxorubicin in these cells. Overall, our results suggest that GS-9973 is selectively interacting with the ABCG2 transporter. The experiments were performed to establish the mechanism of ABCG2 reversal activity by GS-9973 to the substrate drugs, mitoxantrone and doxorubicin.

To evaluate the reversal mechanism of GS-9973, drug accumulation and efflux assays were carried out using the radioactive $\left[{ }^{3} \mathrm{H}\right]$-mitoxantrone in the sensitive, H460 and H460/MX20 (drug-resistant) cells. The intracellular level of $\left[{ }^{3} \mathrm{H}\right]$-mitoxantrone in the resistant cancer cells, which overexpress the ABCG2 transporter, was decreased remarkably compared to that of the parental, drug-sensitive, NCI-H460 cells. In addition, GS-9973 showed a significant increase in the intracellular accumulation of $\left[{ }^{3} \mathrm{H}\right]$-mitoxantrone in the MDR NCI-H460/MX20 cell line in a time-dependent manner but not in the parental NCI-H460 cancer cells. This increase in mitoxantrone accumulation could result from either GS-9973 blocking the pump out action of the ABCG2 transporter and/or increasing the cellular uptake of mitoxantrone. Our results indicated that GS-9973 caused a remarkable, time-dependent rise in the levels of $\left[{ }^{3} \mathrm{H}\right]$-mitoxantrone by blocking the ABCG2 transporter's efflux activity. However, another mechanism by which GS-9973 can increase the efficacy of certain anticancer drugs that are ABCG2 substrates is by decreasing the expression of the ABCG2 protein. Based on the $\left[{ }^{3} \mathrm{H}\right]$-mitoxantrone results, Western blotting and PCR experiments were carried out to figure out the reversal effect of GS-9973 on the in vitro expression of the ABCG2 transporter protein in the MDR NCI-H460/MX20 cancer cells. The
A

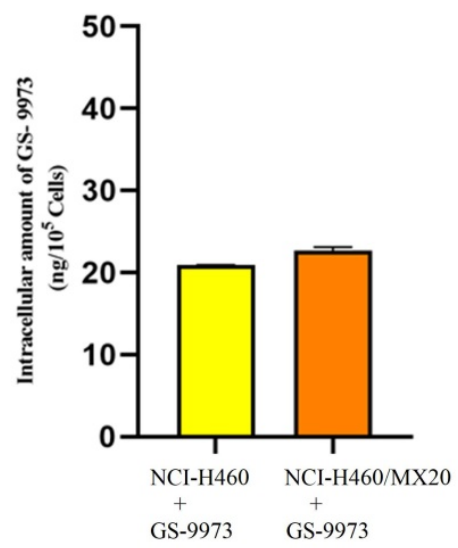

B

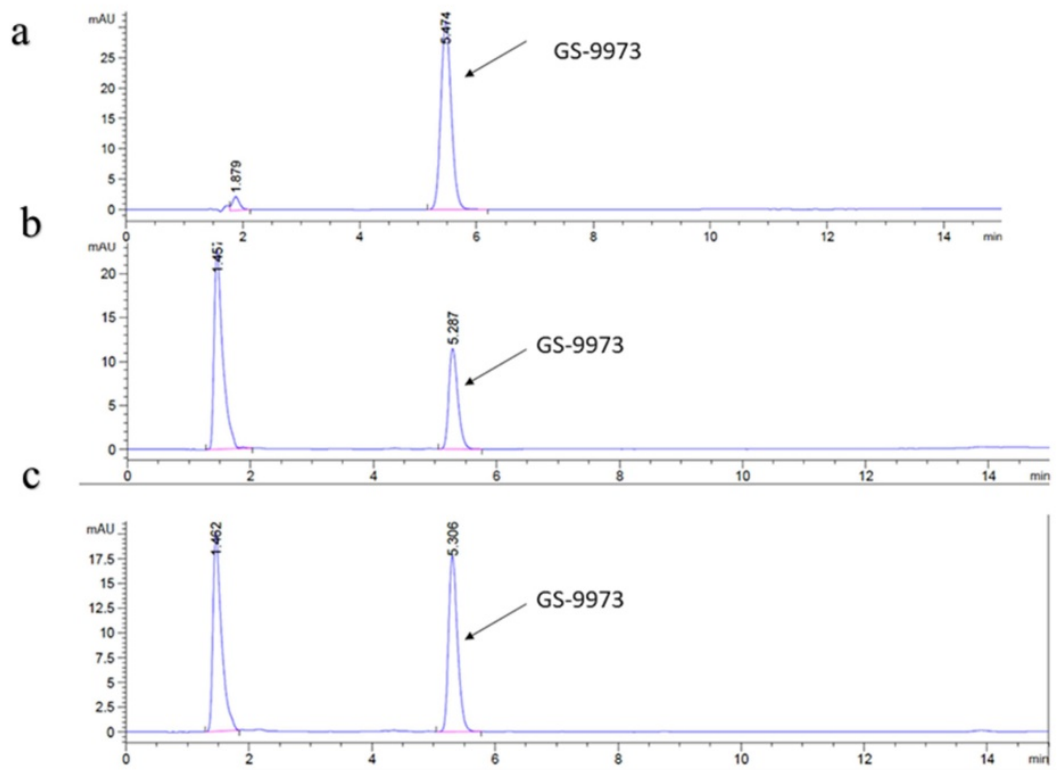

Figure 9. (A) The intracellular accumulation of GS-9973 in $\mathrm{NCl}-\mathrm{H} 460$ and $\mathrm{NCl}-\mathrm{H} 460 / \mathrm{MX20}$. Data are expressed as mean \pm SD from three independent experiments. (B) HPLC trace at $254 \mathrm{~nm}$ for: a) GS-9973, b) Accumulation of GS-9973 in NCl-H460, c) Accumulation of GS-9973 in NCl-H460/MX20. 
data demonstrated that the treatment of NCI-H460/MX20 cells with $3 \mu$ M of GS-9973 for $72 \mathrm{~h}$ notably downregulates the ABCG2 protein compared to control but no change in ABCG2 expression at mRNA level. These results suggested that the downregulation of ABCG2 by GS-9973 occurred only at the translational level probably due to posttranslational modification. Therefore, in this study, it is proven that the increase in the anticancer efficacy of substrate drugs, mitoxantrone and doxorubicin in the drug-resistant cells results from a downregulation of the ABCG2 transporter protein and by inhibiting the transporter function. It is also possible that GS-9973 could change the localization of the ABCG2 protein from the cell membrane, thus decreasing the number of ABCG2 transporter available for drug efflux. As a result, in vitro immunofluorescent experiment was conducted to discover the effect of GS-9973 on the subcellular localization of the ABCG2 protein from the cell membrane to the cytosol and the result suggested GS-9973 could not remarkably modify the location of the ABCG2 protein in NCI-H460/MX20, compared to the vehicle. However, we cannot eliminate the possibility that longer incubation times with GS-9973 may have significantly altered the cellular distribution of the ABCG2 transporter.

The efflux function of the ABCG2 transporter is coupled to ATP hydrolysis, the drug can act by inhibiting the ATPase or by stimulating the ATPase, we demonstrated the in vitro activity of GS-9973 on the hydrolysis of ATP by the ATPase domain of the ABCG2 transporter. Our results showed that GS-9973 caused a moderate concentration-dependent rise in ATPase activity which could be due to the interaction with the drug-substrate binding site present in the transmembrane domain and competitively blocking the efflux of the ABCG2 transporter substrates. Combining this data with other results, suggests that GS-9973 may interact with the transporter at the drug-binding site, hindering the binding and extrusion of other ABCG2 substrates, thereby sensitize ABCG2-overexpressing cell lines to mitoxantrone and doxorubicin.

To evaluate the mechanism of GS-9973, we performed molecular docking analysis to study the interaction of GS-9973 with the ABCG2 transporter, using a human ABCG2 model. The docking data proves that GS-9973 interacts with the drug-substrate binding pocket in the human homology model of the ABCG2 transporter and prevents the binding of other substrates to the transporter, thereby preventing the efflux of substrates such as mitoxantrone.

As GS-9973 was identified to interact with the ABCG2 transporter, HPLC analysis was carried out to prove that the overexpression of the ABCG2 transporter did not confer resistance to GS-9973. HPLC analysis was conducted to determine the intracellular accumulation of GS-9973 in NCI-H460 cells and in the drug-resistant NCI-H460/MX20 cells. The results show that the intracellular concentration of GS-9973 is not significantly altered in both parental and resistant cell lines and hence, we hypothesize that the drug-binding causes structural changes and inhibits the efflux of other substrates which warrants future investigation.

In conclusion, this study presents the importance of GS-9973 as a modulator of the ABCG2 transporter. In cancer patients, a combination of GS-9973 and ABCG2 substrate drugs is a beneficial treatment option for cells with high ABCG2 expression. Finally, it is important to note that the in vitro results are insufficient for determining the potential clinical use of a drug and therefore, further data must be obtained using in vivo animal models to determine the efficacy and safety of GS-9973.

\section{Acknowledgements}

We are thankful to Dr. Susan E. Bates (Columbia University, NY) and Robert W. Robey (NIH, MD) for the cell lines.

\section{Funding}

This project was funded by St. John's University Research Seed Grant (No. 579-1110-7002), Guangdong Medical Scientific Technology Foundation (No. A2019529) and Department of Pharmaceutical Sciences, St. John's University.

\section{Competing Interests}

The authors have declared that no competing interest exists.

\section{References}

1. Ferlay J, Colombet M, Soerjomataram I, Parkin DM, Piñeros M, Znaor A, et al. Cancer statistics for the year 2020: An overview. Int J Cancer [Internet]. 2021 Apr 5;n/a(n/a). Available from: https://doi.org/10.1002/ijc.33588.

2. Chang A. Chemotherapy, chemoresistance and the changing treatment landscape for NSCLC. Lung cancer. 2011;71(1):3-10.

3. Zhang YK, Zhang XY, Zhang GN, Wang YJ, Xu H, Zhang D, et al. Selective reversal of BCRP-mediated MDR by VEGFR-2 inhibitor ZM323881. Biochem Pharmacol. 2017/03/01. 2017;132:29-37.

4. Vansteenkiste J, Wauters E, Reymen B, Ackermann CJ, Peters S, De Ruysscher D. Current status of immune checkpoint inhibition in early-stage NSCLC. Ann Oncol. 2019/05/31. 2019;30(8):1244-53.

5. Narayanan S, Gupta P, Nazim U, Ali M, Karadkhelkar N, Ahmad M, et al. Anti-cancer effect of Indanone-based thiazolyl hydrazone derivative on colon cancer cell lines. Int J Biochem Cell Biol [Internet]. 2019;110:21-8. Available from: http://www.sciencedirect.com/science/article/pii/ S135727251930038X

6. Singh A, Wu H, Zhang P, Happel C, Ma J, Biswal S. Expression of ABCG2 (BCRP) is regulated by Nrf2 in cancer cells that confers side population and chemoresistance phenotype. Mol Cancer Ther. 2010;9(8):2365-76.

7. Zhao Y, Lu H, Yan A, Yang Y, Meng Q, Sun L, et al. ABCC3 as a marker for multidrug resistance in non-small cell lung cancer. Sci Rep. 2013;3:3120.

8. Kim ES. Chemotherapy resistance in lung cancer. In: Lung Cancer and Personalized Medicine. Springer; 2016. p. 189-209.

9. Wang L, Liu X, Ren Y, Zhang J, Chen J, Zhou W, et al. Cisplatin-enriching cancer stem cells confer multidrug resistance in non-small cell lung cancer via enhancing TRIB1/HDAC activity. Cell Death Dis. 2017;8(4):e2746-e2746. 
10. Uramoto $H$, Tanaka F. Recurrence after surgery in patients with NSCLC. Transl lung cancer Res [Internet]. 2014 Aug;3(4):242-9. Available from: https://pubmed.ncbi.nlm.nih.gov/25806307.

11. Narayanan S, Cai C-Y, Assaraf YG, Guo H-Q, Cui Q, Wei L, et al. Targeting the ubiquitin-proteasome pathway to overcome anti-cancer drug resistance. Drug Resist Updat [Internet]. 2020;48:100663. Available from: http://www. sciencedirect.com/science/article/pii/S1368764619300603.

12. De Vera AA, Gupta P, Lei Z, Liao D, Narayanan S, Teng Q, et al. Immunooncology agent IPI-549 is a modulator of P-glycoprotein (P-gp, MDR1, $\mathrm{ABCB} 1)$-mediated multidrug resistance (MDR) in cancer: In vitro and in vivo. Cancer Lett. 2019 Feb;442:91-103.

13. Baguley BC. Multiple drug resistance mechanisms in cancer. Mol Biotechnol. 2010;46(3):308-16.

14. Chen $Z$, Shi $T$, Zhang $L$, Zhu $P$, Deng M, Huang $C$, et al. Mammalian drug efflux transporters of the ATP binding cassette (ABC) family in multidrug resistance: A review of the past decade. Cancer Lett [Internet]. 2016;370(1):153-64. Available from: http://www.sciencedirect.com/science/ article/pii/S0304383515006278

15. Mansoori B, Mohammadi A, Davudian S, Shirjang S, Baradaran B. The Different Mechanisms of Cancer Drug Resistance: A Brief Review. Adv Pharm Bull. 2017/09/25. 2017 Sep;7(3):339-48.

16. Narayanan S, Teng Q-X, Koya J, Wang J, Assaraf YG, Ashby Jr CR, et al. Poly (ADP-ribose) polymerase (PARP) inhibitors as chemosensitizing compounds for the treatment of drug resistant cancers. J Mol Clin Med. 2019;2(3):55-67.

17. Lage $\mathrm{H}$. An overview of cancer multidrug resistance: a still unsolved problem. Cell Mol life Sci. 2008;65(20):3145.

18. Gillet J-P, Gottesman MM. Mechanisms of multidrug resistance in cancer. Methods Mol Biol. 2010;596:47-76

19. Gupta P, Xie M, Narayanan S, Wang Y-J, Wang X-Q, Yuan T, et al. GSK1904529A, a Potent IGF-IR Inhibitor, Reverses MRP1-Mediated Multidrug Resistance. J Cell Biochem [Internet]. 2017/05/03. 2017 Oct;118(10):3260-7. Available from: https://www.ncbi.nlm.nih.gov/pubmed/28266043.

20. Eckford PDW, Sharom FJ. ABC efflux pump-based resistance to chemotherapy drugs. Chem Rev. 2009;109(7):2989-3011.

21. Amiri-Kordestani L, Basseville A, Kurdziel K, Fojo AT, Bates SE. Targeting MDR in breast and lung cancer: discriminating its potential importance from the failure of drug resistance reversal studies. Drug Resist Updat. 2012;15(12):50-61.

22. Choi $\mathrm{YH}, \mathrm{Yu}$ A-M. ABC transporters in multidrug resistance and pharmacokinetics, and strategies for drug development. Curr Pharm Des [Internet]. 2014;20(5):793-807. Available from: https://pubmed.ncbi.nlm.nih. gov/23688078.

23. Doyle LA, Yang W, Abruzzo L V, Krogmann T, Gao Y, Rishi AK, et al. A multidrug resistance transporter from human MCF-7 breast cancer cells. Proc Natl Acad Sci U S A [Internet]. 1998 Dec 22;95(26):15665-70. Available from: https://www.ncbi.nlm.nih.gov/pubmed/9861027.

24. Nakanishi T, Ross DD. Breast cancer resistance protein (BCRP/ABCG2): its role in multidrug resistance and regulation of its gene expression. Chin J Cancer [Internet]. 2011/11/18. 2012 Feb;31(2):73-99. Available from: https:// www.ncbi.nlm.nih.gov/pubmed/22098950.

25. Mao Q, Unadkat JD. Role of the breast cancer resistance protein (ABCG2) in drug transport. Aaps j. 2005/09/09. 2005;7(1):E118-33.

26. Polgar O, Robey RW, Bates SE. ABCG2: structure, function and role in drug response. Expert Opin Drug Metab Toxicol. 2008;4(1):1-15.

27. Fletcher JI, Williams RT, Henderson MJ, Norris MD, Haber M. ABC transporters as mediators of drug resistance and contributors to cancer cell biology. Drug Resist Updat Rev Comment Antimicrob Anticancer Chemother. 2016 May;26:1-9.

28. Huo $Q$, Yuan J, Zhu T, Xie* ZL and N. A Combined Bioinformatic and Nanoparticle-Based Study Reveal the Role of ABCG2 in the Resistance of Breast Cancer [Internet]. Vol. 16, Recent Patents on Anti-Cancer Drug Discovery. 2021. p. 1. Available from: http://www.eurekaselect.com/node/ 191581/article.

29. Yu Y, Durairaj C, Shi H, Wang DD. Population Pharmacokinetics of Talazoparib in Patients With Advanced Cancer. J Clin Pharmacol [Internet]. 2020;60(2):218-28. Available from: http://europepmc.org/abstract/MED/ 31489639 .

30. Manegold C, Dingemans A-MC, Gray JE, Nakagawa K, Nicolson M, Peters S, et al. The potential of combined immunotherapy and antiangiogenesis for the synergistic treatment of advanced NSCLC. J Thorac Oncol. 2017;12(2):194-207.

31. Besse B, Adjei A, Baas P, Meldgaard P, Nicolson M, Paz-Ares L, et al. 2nd ESMO Consensus Conference on Lung Cancer: non-small-cell lung cancer first-line/second and further lines of treatment in advanced disease. Ann Oncol [Internet]. 2014;25(8):1475-84. Available from: http://www. sciencedirect.com/science/article/pii/S0923753419348082.

32. Alvarez JGB, González-Cao M, Karachaliou N, Santarpia M, Viteri S, Teixidó $\mathrm{C}$, et al. Advances in immunotherapy for treatment of lung cancer. Cancer Biol Med. 2015;12(3):209.

33. Herbst RS, Morgensztern D, Boshoff C. The biology and management of non-small cell lung cancer. Nature. 2018;553(7689):446-54.

34. Robey RW, Honjo Y, Morisaki K, Nadjem TA, Runge S, Risbood M, et al. Mutations at amino-acid 482 in the ABCG 2 gene affect substrate and antagonist specificity. Br J Cancer. 2003;89(10):1971-8

35. Hambardzumyan D, Becher OJ, Holland EC. Cancer stem cells and survival pathways. Cell Cycle. 2008;7(10):1371-8.
36. Zhao X, Dai C, Ohnuma S, Liang $Y$, Deng $W$, Chen J-J, et al. Tandutinib (MLN518/CT53518) targeted to stem-like cells by inhibiting the function of ATP-binding cassette subfamily G member 2. Eur J Pharm Sci. 2013;49(3):441-

37. Li F, Zeng H, Ying K. The combination of stem cell markers CD133 and ABCG2 predicts relapse in stage I non-small cell lung carcinomas. Med Oncol. 2011;28(4):1458-62.

38. Hang D, Dong H-C, Ning T, Dong B, Hou D-L, Xu W-G. Prognostic value of the stem cell markers CD133 and ABCG2 expression in esophageal squamous cell carcinoma. Dis Esophagus. 2012;25(7):638-44.

39. Dohse M, Scharenberg C, Shukla S, Robey RW, Volkmann T, Deeken JF, et al. Comparison of ATP-binding cassette transporter interactions with the tyrosine kinase inhibitors imatinib, nilotinib, and dasatinib. Drug Metab Dispos [Internet]. 04/27. 2010;38(8):1371-80. Available from: https://pubmed. ncbi.nlm.nih.gov/20423956; https://www.ncbi.nlm.nih.gov/pmc/articles/ PMC2913625/.

40. Hegedüs C, Truta-Feles K, Antalffy G, Várady G, Német K, Özvegy-Laczka C, et al. Interaction of the EGFR inhibitors gefitinib, vandetanib, pelitinib and neratinib with the ABCG2 multidrug transporter: Implications for the emergence and reversal of cancer drug resistance. Biochem Pharmacol [Internet]. 2012;84(3):260-7. Available from: http://www.sciencedirect.com/ science/article/pii/S0006295212002900

41. Barbuti AM, Zhang G-N, Gupta P, Narayanan S, Chen Z-S. Chapter 1 - EGFR and HER2 Inhibitors as Sensitizing Agents for Cancer Chemotherapy. In: Chen Z-S, Yang D-HBT-PKI as SA for C, editors. Cancer Sensitizing Agents for Chemotherapy [Internet]. Academic Press; 2019. p. 1-11. Available from: http://www.sciencedirect.com/science/article/pii/B9780128164358000018.

42. Gupta P, Narayanan S, Yang D-H. Chapter 9 - CDK Inhibitors as Sensitizing Agents for Cancer Chemotherapy. In: Chen Z-S, Yang D-HBT-PKI as SA for C, editors. Cancer Sensitizing Agents for Chemotherapy [Internet]. Academic Press; 2019. p. 125-49. Available from: http://www.sciencedirect.com/ science/article/pii/B9780128164358000092.

43. Galetti M, Petronini PG, Fumarola C, Cretella D, La Monica S, Bonelli M, et al. Effect of ABCG2/BCRP expression on efflux and uptake of gefitinib in NSCLC cell lines. PLoS One. 2015:10(11):e0141795.

44. Lei Z-N, Teng Q-X, Gupta P, Zhang W, Narayanan S, Yang D-H, et al. Cabozantinib Reverses Topotecan Resistance in Human Non-Small Cell Lung Cancer NCI-H460/TPT10 Cell Line and Tumor Xenograft Model. Front Cell Dev Biol [Internet]. 2021;9:643. Available from: https://www.frontiersin.org/ article/10.3389/fcell.2021.640957.

45. Zhang Y-K, Wang Y-J, Lei Z-N, Zhang G-N, Zhang X-Y, Wang D-S, et al. Regorafenib antagonizes BCRP-mediated multidrug resistance in colon cancer. Cancer Lett. 2019 Feb;442:104-12.

46 Zhang G-N, Zhang Y-K, Wang Y-J, Gupta P, Ashby Jr CR, Alqahtani S, et al. Epidermal growth factor receptor (EGFR) inhibitor PD153035 reverses ABCG2-mediated multidrug resistance in non-small cell lung cancer: in vitro and in vivo. Cancer Lett. 2018;424:19-29.

47. Yanagi $\mathrm{S}$, Inatome $\mathrm{R}$, Takano $\mathrm{T}$, Yamamura $\mathrm{H}$. Syk expression and novel function in a wide variety of tissues. Biochem Biophys Res Commun. 2001;288(3):495-8

48. Riccaboni M, Bianchi I, Petrillo P. Spleen tyrosine kinases: biology, therapeutic targets and drugs. Drug Discov Today [Internet]. 2010;15(13):517-30. Available from: http://www.sciencedirect.com/science/article/pii/ S1359644610001510.

49. Sharman J, Hawkins M, Kolibaba $K$, Boxer M, Klein $\mathrm{L}, \mathrm{Wu} M$, et al An open-label phase 2 trial of entospletinib (GS-9973), a selective spleen tyrosine kinase inhibitor, in chronic lymphocytic leukemia. Blood [Internet]. 2015;125(15):2336-43. Available from: https://doi.org/10.1182/blood-2014$08-595934$.

50. Walker AR, Bhatnagar B, Marcondes AMQ, DiPaolo J, Vasu S, Mims AS, et al. Interim Results of a Phase 1b/2 Study of Entospletinib (GS-9973) Monotherapy and in Combination with Chemotherapy in Patients with Acute Myeloid Leukemia. Blood [Internet]. 2016;128(22):2831. Available from: https://doi.org/10.1182/blood.V128.22.2831.2831.

51. Andorsky DJ, Kolibaba KS, Assouline S, Forero-Torres A, Jones V, Klein LM, et al. An open-label phase 2 trial of entospletinib in indolent non-Hodgkin lymphoma and mantle cell lymphoma. Br J Haematol. 2018/09/06. 2019;184(2):215-22.

52. Robey RW, Honjo $\mathrm{Y}$, van de Laar A, Miyake $\mathrm{K}$, Regis JT, Litman $\mathrm{T}$, et al. A functional assay for detection of the mitoxantrone resistance protein, MXR (ABCG2). Biochim Biophys Acta. 2001 Jun;1512(2):171-82

53. Robey RW, Honjo Y, Morisaki K, Nadjem TA, Runge S, Risbood M, et al. Mutations at amino-acid 482 in the ABCG2 gene affect substrate and antagonist specificity. Br J Cancer [Internet]. 2003 Nov 17;89(10):1971-8. Available from: https://www.ncbi.nlm.nih.gov/pubmed/14612912.

54. Chen L, Manautou JE, Rasmussen TP, Zhong X. Development of precision medicine approaches based on inter-individual variability of BCRP/ABCG2. Acta Pharm Sin B [Internet]. 2019;9(4):659-74. Available from: http://www. sciencedirect.com/science/article/pii/S2211383518309158.

55. Yang Y, Liu Y, Dong Z, Xu J, Peng H, Liu Z, et al. Regulation of Function by Dimerization through the Amino-terminal Membrane-spanning Domain of Human ABCC1/MRP1. J Biol Chem. 2007 Apr 1;282:8821-30.

56. Wang D-S, Patel A, Sim H-M, Zhang Y-K, Wang Y-J, Kathawala RJ, et al. ARRY-334543 reverses multidrug resistance by antagonizing the activity of ATP-binding cassette subfamily G member 2. J Cell Biochem [Internet]. 2014 
Aug;115(8):1381-91. Available from: https://pubmed.ncbi.nlm.nih.gov/ 24939447.

57. Wong T, Narayanan S, Brown DP, Chen Z-S. Synthesis and Cytotoxicity Studies of Stilbene Long-Chain Fatty Acid Conjugates. J Nat Prod [Internet]. 2020 May 22;83(5):1563-70. Available from: https://doi.org/10.1021/acs. jnatprod.0c00027.

58. Carmichael J, DeGraff WG, Gazdar AF, Minna JD, Mitchell JB. Evaluation of a Tetrazolium-based Semiautomated Colorimetric Assay: Assessment of Chemosensitivity Testing. Cancer Res [Internet]. 1987 Feb 15;47(4):936 LP 942. Available from: http://cancerres.aacrjournals.org/content/47/4/936. abstract.

59. Bahuguna A, Khan I, Bajpai VK, Chul S. MTT assay to evaluate the cytotoxic potential of a drug. Bangladesh J Pharmacol. 2017 Apr 8;12:8.

60. Narayanan S, Gujarati NA, Wang J-Q, Wu Z-X, Koya J, Cui Q, et al. The Novel Benzamide Derivative, VKNG-2, Restores the Efficacy of Chemotherapeutic Drugs in Colon Cancer Cell Lines by Inhibiting the ABCG2 Transporter. Int J Mol Sci [Internet]. 2021 Feb 28;22(5):2463. Available from: https://pubmed. ncbi.nlm.nih.gov/33671108.

61. Wang J-Q, Li JY, Teng Q-X, Lei Z-N, Ji N, Cui Q, et al. Venetoclax, a BCL-2 Inhibitor, Enhances the Efficacy of Chemotherapeutic Agents in Wild-Type ABCG2-Overexpression-Mediated MDR Cancer Cells. Cancers (Basel). 2020 Feb;12(2).

62. Ji N, Yang Y, Cai C-Y, Lei Z-N, Wang J-Q, Gupta P, et al. VS-4718 Antagonizes Multidrug Resistance in ABCB1- and ABCG2-Overexpressing Cancer Cells by Inhibiting the Efflux Function of $\mathrm{ABC}$ Transporters. Front Pharmacol [Internet]. 2018;9:1236. Available from: https://www.frontiersin.org/article/ 10.3389/fphar.2018.01236.

63. Shukla S, Jhamtani R, Dahiya M, Agarwal DR. A novel method to achieve high yield of total RNA from zebrafish for expression studies. Vol. 6, International Journal of Bioassays. 2017. $5383 \mathrm{p}$.

64. Zhang W, Fan Y-F, Cai C-Y, Wang J-O Teng Q-X, Lei Z-N, et al Olmutinib (BI1482694/HM61713), a Novel Epidermal Growth Factor Receptor Tyrosine Kinase Inhibitor, Reverses ABCG2-Mediated Multidrug Resistance in Cancer Cells. Front Pharmacol [Internet]. 2018 Oct 9;9:1097. Available from: https:// pubmed.ncbi.nlm.nih.gov/30356705.

65. Patel BA, Abel B, Barbuti AM, Velagapudi UK, Chen Z-S, Ambudkar S V, et al. Comprehensive Synthesis of Amino Acid-Derived Thiazole Peptidomimetic Analogues to Understand the Enigmatic Drug/Substrate-Binding Site of P-Glycoprotein. J Med Chem. 2018 Feb;61(3):834-64.

66. Manolaridis I, Jackson SM, Taylor NMI, Kowal J, Stahlberg H, Locher KP. Cryo-EM structures of a human ABCG2 mutant trapped in ATP-bound and substrate-bound states. Nature. $2018 \mathrm{Nov} ; 563(7731): 426-30$.

67. Friesner RA, Murphy RB, Repasky MP, Frye LL, Greenwood JR, Halgren TA, et al. Extra Precision Glide: Docking and Scoring Incorporating a Model of Hydrophobic Enclosure for Protein-Ligand Complexes. J Med Chem [Internet]. 2006 Oct 1;49(21):6177-96. Available from: https://doi.org/ $10.1021 /$ jm051256o.

68. Wu Z-X, Peng Z, Yang Y, Wang J-O Teng Q-X, Lei Z-N, et al. M3814, a DNA-PK Inhibitor, Modulates ABCG2-Mediated Multidrug Resistance in Lung Cancer Cells. Front Oncol [Internet]. 2020;10:674. Available from: https:// www.frontiersin.org/article/10.3389/fonc.2020.00674.

69. Vesel M, Rapp J, Feller D, Kiss E, Jaromi L, Meggyes M, et al. ABCB1 and ABCG2 drug transporters are differentially expressed in non-small cell lung cancers (NSCLC) and expression is modified by cisplatin treatment via altered Wnt signaling. Respir Res [Internet]. 2017 Mar 24;18(1):52. Available from: https:// pubmed.ncbi.nlm.nih.gov/28340578.

70. Guo X, To KKW, Chen Z, Wang X, Zhang J, Luo M, et al. Dacomitinib potentiates the efficacy of conventional chemotherapeutic agents via inhibiting the drug efflux function of ABCG2 in vitro and in vivo. J Exp Clin Cancer Res [Internet]. 2018;37(1):31. Available from: https://doi.org/10.1186/ s13046-018-0690-x

71. Mócsai A, Ruland J, Tybulewicz VLJ. The SYK tyrosine kinase: a crucial player in diverse biological functions. Nat Rev Immunol. 2010 Jun;10(6):387-402.

72. Geahlen RL. Getting Syk: spleen tyrosine kinase as a therapeutic target. Trends Pharmacol Sci. 2014 Aug:35(8):414-22.

73. Burke RT, Meadows S, Loriaux MM, Currie KS, Mitchell SA, Maciejewski P, et al. A potential therapeutic strategy for chronic lymphocytic leukemia by combining Idelalisib and GS-9973, a novel spleen tyrosine kinase (Syk) inhibitor. Oncotarget [Internet]. $2014 \mathrm{Feb}$ 28:5(4):908-15. Available from: https://pubmed.ncbi.nlm.nih.gov/24659719.

74. Weidner LD, Zoghbi SS, Lu S, Shukla S, Ambudkar S V, Pike VW, et al. The Inhibitor Ko143 Is Not Specific for ABCG2. J Pharmacol Exp Ther [Internet]. 2015/07/06. 2015 Sep;354(3):384-93. Available from: https://pubmed.ncbi. nlm.nih.gov/26148857.

75. Allen JD, Jackson SC, Schinkel AH. A mutation hot spot in the Bcrp1 (Abcg2) multidrug transporter in mouse cell lines selected for Doxorubicin resistance. Cancer Res. 2002 Apr;62(8):2294-9.

76. Volk EL, Farley KM, Wu Y, Li F, Robey RW, Schneider E. Overexpression of wild-type breast cancer resistance protein mediates methotrexate resistance. Cancer Res. 2002 Sep;62(17):5035-40.

77. Toyoda Y, Takada T, Suzuki H. Inhibitors of Human ABCG2: From Technical Background to Recent Updates With Clinical Implications. Front Pharmacol [Internet]. 2019;10:208. Available from: https://www.frontiersin.org/article/ 10.3389/fphar.2019.00208. 